\title{
ESG: Research Progress and Future Prospects
}

\author{
Ting-Ting $\mathrm{Li}^{1, *}$, Kai Wang ${ }^{1}$, Toshiyuki Sueyoshi ${ }^{2,3}$ and Derek D. Wang ${ }^{1}$ \\ 1 College of Business Administration, Capital University of Economics and Business, Beijing 100070, China; \\ wangkai@cueb.edu.cn (K.W.); wangdd@cueb.edu.cn (D.D.W.) \\ 2 Department of Management, New Mexico Institute of Mining and Technology, Socorro, NM 87801, USA; \\ Toshiyuki.Sueyoshi@nmt.edu \\ 3 School of Environment and Society, Tokyo Tech World Research Hub Initiative, Tokyo Institute of Technology, \\ Tokyo 108-0023, Japan \\ * Correspondence: litingtingcueb@163.com
}

Citation: Li, T.-T.; Wang, K.; Sueyoshi, T.; Wang, D.D. ESG: Research Progress and Future Prospects. Sustainability 2021, 13, 11663. https://doi.org/10.3390/ su132111663

Academic Editor: Fernando Almeida

Received: 30 June 2021

Accepted: 11 October 2021

Published: 21 October 2021

Publisher's Note: MDPI stays neutral with regard to jurisdictional claims in published maps and institutional affiliations.

Copyright: (C) 2021 by the authors. Licensee MDPI, Basel, Switzerland. This article is an open access article distributed under the terms and conditions of the Creative Commons Attribution (CC BY) license (https:/ / creativecommons.org/licenses/by/ $4.0 /)$.

\begin{abstract}
The sustainable development of the global economy and society calls for the practice of the environmental, social and governance (ESG) principle. The ESG principle has been developed for 17 years following its formal proposal in 2004. Countries around the world continue to promote the coordinated development of the environment, society, and governance in accordance with the ESG principle. In order to review and summarize ESG research, this study takes the literature related to ESG research as the research object and presents the cooperation status, hot spots, and trends of ESG research with the help of the literature analysis tool CiteSpace. On the basis of quantitative analysis results, this study presents an examination and comprehensive summary of progress in the research into ESG combined with a systematic literature review. This includes the theoretical basis of ESG research, the interaction between the dimensions of ESG, the impact of ESG on the economic consequences, the risk prevention role of ESG, and ESG measurement. Based on the systematic summary of research progress, this paper further refines the characteristics of ESG research, reveals the shortcomings of ESG research, and propose a focus for ESG research in the future in order to provide a reference for academic research and the practice of ESG.
\end{abstract}

Keywords: ESG; bibliometric; literature review; future research navigation

\section{Introduction}

Human society never ceases in its pursuit of progress. Today, with the development of the economy and society, the world is faced with not only many opportunities, but also challenges. In 2020, “Black Swan" events occurred frequently. With the global spread of COVID-19, four meltdowns in the US stock market in a fortnight, the plague of locusts in Africa, Luckin Coffee being delisted following fraud, etc., environmental (E), social (S), and governance $(\mathrm{G})$ issues have aroused global concern. The theme of sustainable and comprehensive development has, once again, become a hot topic of discussion worldwide. In response to the increasingly severe sustainable development problems in the environment, society, and the financial market, international organizations and countries worldwide have put forward sustainable development action plans such as ESG to build a sustainable and comprehensive development framework of human society.

The ESG principle is a framework system including environmental (E), social (S), and governance $(G)$ factors (see Table 1) [1]. ESG stems from responsible investment. The principles for responsible investment (PRI) define responsible investment as "a strategy and practice to incorporate environmental, social and governance (ESG) factors in investment decisions and active ownership" [2]. Therefore, ESG is usually a standard and strategy used by investors to evaluate corporate behavior and future financial performance. As an investment concept for evaluating the sustainable development of enterprises, the three basic factors of ESG are the key points to be considered in the process of investment analysis and decision making. Moreover, environmental, social, and governance (ESG) factors help 
to measure the sustainability and social impact of business activities [3]. As the EBA (European Banking Authority) states, ESG factors are "environmental, social or governance matters that may have a positive or negative impact on the financial performance or solvency of an entity, sovereign or individual" [1]. Therefore, as a value of sustainable and coordinated development that takes into account economic, environmental, social, and governance benefits, ESG is an investment philosophy that pursues long-term value growth, and it is a comprehensive, concrete, and down-to-earth governance method.

Table 1. ESG framework (international frameworks).

\begin{tabular}{|c|c|c|}
\hline Dimension & Factors & Definition \\
\hline Environmental (E) & $\begin{array}{ll}\text { - } & \text { GHG emissions } \\
\text { - } & \text { Energy consumption and efficiency } \\
\text { - } & \text { Wir pollutants } \\
\text { - } & \text { Waste production and management (water, } \\
\text { - } & \text { solid, hazardous) } \\
\text { - } & \text { Impact and dependence on biodiversity } \\
\text { - } & \text { Innovation in environmentally friendly } \\
& \text { products and services }\end{array}$ & $\begin{array}{l}\text { Environmental matters that may have a } \\
\text { positive or negative impact on the } \\
\text { financial performance or solvency of an } \\
\text { entity, sovereign, or individual. }\end{array}$ \\
\hline Social (S) & $\begin{array}{ll}\text { - } & \text { Workforce freedom of association } \\
\text { - } & \text { Child labor } \\
\text { - } & \text { Forced and compulsory labor } \\
\text { - } & \text { Workplace health and safety } \\
\text { - } & \text { Customer health and safety } \\
\text { - } & \text { Discrimination, diversity, and equal } \\
\text { - } & \text { Opportunity } \\
\text { - } & \text { Poverty and community impact } \\
\text { - } & \text { Supply chain management } \\
\text { - } & \text { Training and education } \\
\text { - } & \text { Customer privacy } \\
\text { - } & \text { Community impacts }\end{array}$ & $\begin{array}{l}\text { Social matters that may have a positive } \\
\text { or negative impact on the financial } \\
\text { performance or solvency of an entity, } \\
\text { sovereign, or individual. }\end{array}$ \\
\hline
\end{tabular}

- Codes of conduct and business principles

- Accountability

- Transparency and disclosure

$\begin{array}{lll}\text { Governance }(\mathrm{G}) & \bullet & \text { Executive pay } \\ & \bullet & \text { Board diversity and structure }\end{array}$

- Bribery and corruption

- Stakeholder engagement

- Shareholder rights

Source: own elaboration base on the EBA report on ESG risk management and supervision. Available online: https: //www.eba.europa.eu/sites/default/documents/files/document_library/Publications/Reports/2021/1015656/EBA\%20Report\%20 on\%20ESG\%20risks\%20management\%20and\%20supervision.pdf (accessed on 31 July 2021).

Since the ESG principle was formally proposed in 2004, it has been actively practiced in Europe, America, and other developed countries. A series of achievements promote the development and maturity of the environmental, social, and governance factors, as well as ESG as a whole, such as the establishment of the ESG evaluation system, the ESG disclosure standards, and the ESG index system. These factors are constantly building a new pattern of sustainable development. With the concept of ESG gradually becoming mainstream, ESG has been widely examined, practiced, and popularized in the practical field, and it has aroused the interest of scholars from all over the world. At present, there are few literature reviews on ESG research. Moreover, they mainly focus on ESG investment (Daugaard, 2020) [4], the importance of ESG metrics in SRI (socially responsible investment) (Widyawati, 2020) [5], the influence of the ESG score on measuring corporate sustainability performance (Drempetic et al., 2020) [6], the origin and significance of the name of ESG in investment 
(Eccles and Viviers, 2011) [7], and the importance and role of ESG factors in the financial decision-making process (Ziolo et al., 2019) [8]. In addition, there are literature reviews on the role and performance of corporate governance (G) in ESG (Yoshikawa et al., 2021) [9] and discussions of the relationship between corporate governance and corporate social responsibility (Aluchna and Roszkowska-Menkes, 2019) [10]. At present, it can be observed that ESG reviews mainly focus on one aspect of ESG factors, and there is a scarcity of literature on the environmental (E) and social (S) factors. However, after combing the relevant literature of ESG research, this paper finds that ESG, as an integrated framework and concept of environmental, social, and governance factors, displays an interactive relationship between its dimensions, and many studies focusing on the interaction between the environmental $(\mathrm{E})$, social $(\mathrm{S})$, and governance $(\mathrm{G})$ factors have emerged. In addition, the environmental, social, and governance factors play an important role in measuring the future financial performance and social influence of enterprises. Therefore, as an investment principle integrating the environmental, social, and governance factors, ESG is an important driving force to trigger the sustainable development of enterprises, and the interactive relationship between its dimensions is also a key point that deserves attention. In order to promote the global economy and society to improve in quality, this paper systematically reviews the research on ESG and looks forward to the future development direction of ESG research.

The paper is structured as follows. Section 1, introduction including definition of ESG and research background. Section 2, the literature related to the research of ESG is analyzed including the theoretical basis of ESG, the interaction between the three dimensions of ESG, the impact of ESG on economic consequences, the risk prevention role of ESG, and ESG measurement. Section 3 is conclusions and future research.

This paper is expected to arouse the interest of stakeholders who care about and explore the essence and significance of ESG, such as enterprises, government regulators, financial institutions, and academic institutions. At the same time, this paper also provides a useful reference and guidance for the promotion of further development and practice of ESG.

\section{Analysis of ESG Literature in Top International Journals \\ 2.1. Method}

ESG emerged from developed countries such as Europe and the US. The practice and development of ESG in companies are relatively mature. As a result, there is a wealth of literature on ESG research. In order to systematically and objectively review the research achievements of ESG in the last 17 years, this paper presented the research progress of ESG by combining bibliometric analysis with a literature review.

Firstly, this paper used CiteSpace to objectively quantify ESG-related research on "UTD24", and showed the maturity, hot spots, and trends of ESG research with objective data. As bibliometric analysis software with relatively complete functions, CiteSpace has advantages that other bibliometrics software cannot match. In this paper, the use of CiteSpace could directly and objectively show the situation of ESG in academic community cooperation and the hot spots and trends of ESG research.

Secondly, on the basis of the quantitative analysis results, by combing the ESG-related literature in the "UTD24" journal, the interactions between the environmental (E), social (S), and governance $(\mathrm{G})$ factors and ESG's related influencing factors were further summarized, and the results quantified by CiteSpace were verified to clarify the research progress and research trend of ESG since 2004.

Therefore, the bibliometric analysis results and the systematic literature review are mutually connected and verified. This paper presents ESG research in a comprehensive and objective form.

\subsection{Data Collection}

The literature searched in this paper was obtained from the Web of Science (WOS) database of the top journals published in "UTD24" from January 1985 to December 2020, focusing on business, economics, finance, information, marketing, and management science. 
This was because we believe that the above areas are closely related to the ESG practice of a company. In selecting the "topic," we found that although ESG has been proposed, there is no clear definition. Practitioners in various industries and scholars have given different explanations. In order to comprehensively retrieve the literature needed in this paper, after consulting the relevant literature, we found that ESG, corporate responsibility, sustainability, and socio-environmental governance are used as synonyms (Garcia et al., 2017) [11]. In addition, since ESG is derived from CSR, ESG and CSR are two terms that can be used interchangeably (Garcia et al., 2017) [11]. Therefore, the "topic" includes environmental, social, and governance (ESG), corporate social responsibility (CSR), corporate responsibility, sustainability, and socio-environmental governance, which were used in the final search of a total of 793 pieces of literature. The search showed that the related research on the topic of ESG began in 2004. Then, CiteSpace was used to eliminate duplicates, and 593 pieces of literature were selected for bibliometric analysis.

\subsection{Bibliometric Analysis}

\subsubsection{Analysis of Academic Community Collaboration on ESG}

The dynamic, complex nature of professional research fields requires the development of subject areas through research collaboration and the integration of resources at the individual and institutional levels. ESG is an emerging field of research, and in 2004, Kofi Annan and 18 financial institutions drafted the report "Who Cares Wins: Connecting Financial Markets to a Changing World." This report called for the integration of ESG factors into financial analysis, asset management, and security brokerage. The concept of ESG has gradually emerged in Europe and the US. The study of environmental (E), social (S), and governance (G) factors, as well as ESG as a whole, has gradually become an important issue after CSR. The cooperative co-occurrence analysis in CiteSpace can intuitively reflect the degree and level of cooperation in a professional research field. Therefore, first, this paper shows the progress and maturity of ESG research through the level of academic community cooperation.

1. Academic institutions represented by European and American countries have a high level of cooperation.

This paper uses "Country" and "Institution" as network nodes and CiteSpace to map out the cooperation network map of countries and academic institutions. The visualization in Figure 1 shows the maturity and diffusion of the ESG sustainability concept in foreign countries. In the field of ESG research, the cooperation between Europe and the US seems to be close. Taking the top three countries as an example, the US has a frequency of 386 collaborations in ESG and a centrality of 0.91 , and it has been in a partnership since 2004. The frequency of cooperation in Canada is 85 , with a centrality of 0.21 . The frequency of cooperation in the UK is 75 , with a centrality of 0.33. As observed, cooperation in developed countries, such as the United States, Canada, and the United Kingdom, shows a highly centralized and high level of practice. In terms of collaborating institutions, academic institutions represented by Harvard University, the University of Pennsylvania, the University of Minnesota, and Boston University have strong collaborative links in ESG research, with a frequency of $16,16,15$, and 14 collaborations, respectively, and centrality of $0.02,0.04,0.01$, and 0.03 , respectively. Compared to developed countries, such as those in Europe and the US, the level of research cooperation in ESG in developing countries, represented by China, is relatively low.

2. The cooperation network among scholars is decentralized, and the degree of cooperation is low.

CiteSpace is used in this study for author cooperation co-occurrence to demonstrate the network and profile of author collaborations in the field. The timeline set here is from 2004 to 2020, and the time slice is set to 5 years. The resulting graph of the author cooperation network is shown in Figure 2. After clustering, it can be observed that modularity $=0.8834$, which is greater than 0.3 , and silhouette $=0.9672$, which is greater than 0.7 , indicating a significant and 
plausible clustering structure. As seen from the authors' collaboration map, ESG research has formed a collaborative network centered on the works of Christopher Marquis, Caroline Flammer, Rodolphe Durand, Donal Crilly, George Serafeim, Michael D. Pfarrer, Heli Wang, and other scholars. However, there is a lack of close and extensive collaborative links between each team. In general, the network structure of collaboration among scholars on ESG research is too fragmented, and the level of collaboration among scholars is low.

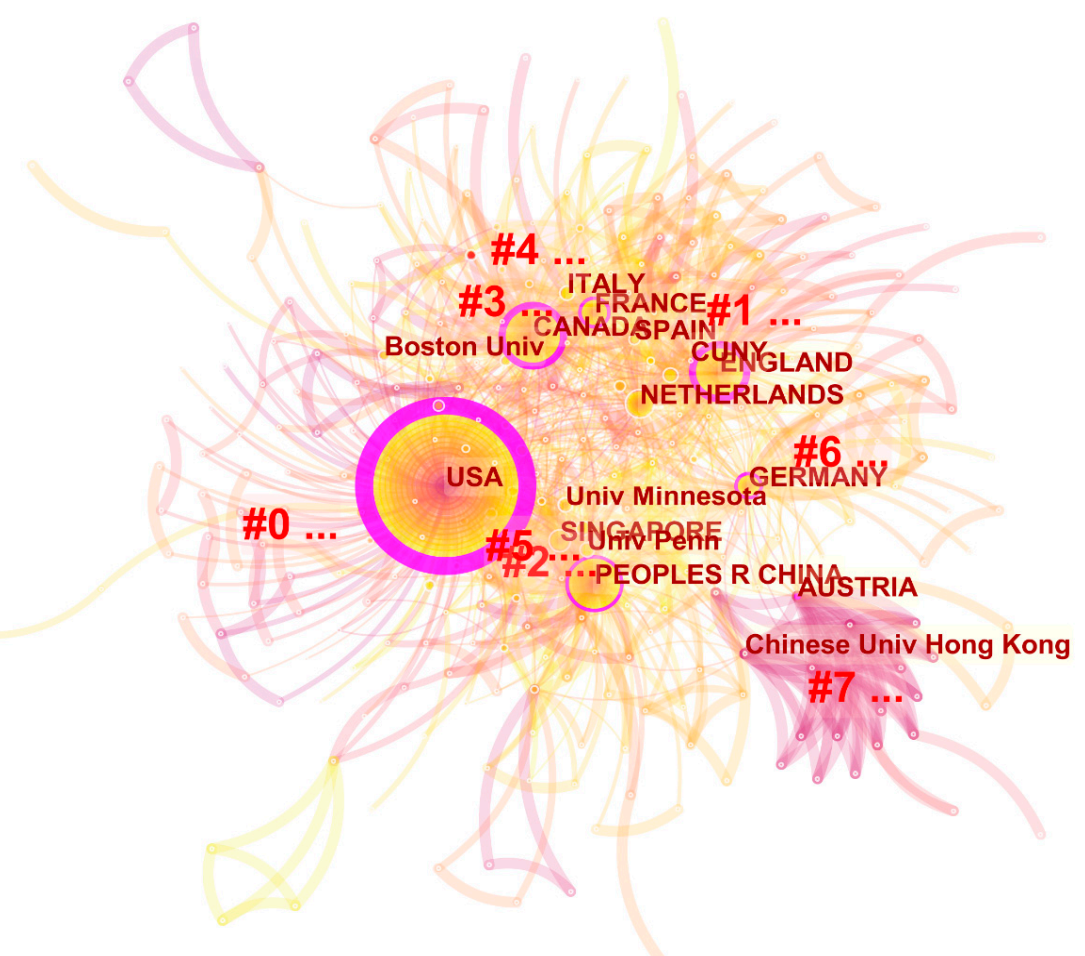

Figure 1. Collaboration network among countries and academic institutions. Source: mapped by CiteSpace.

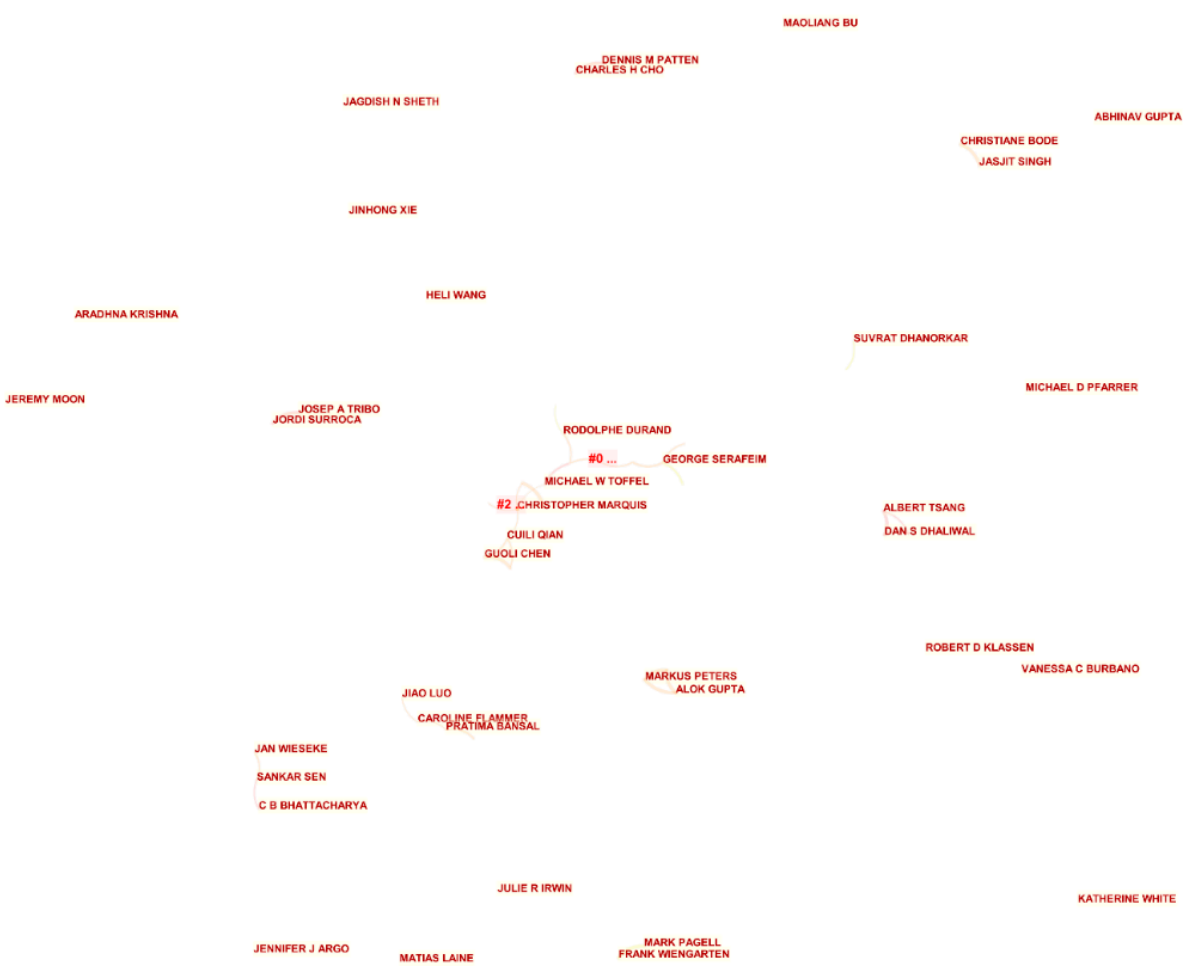

Figure 2. Author collaboration network. Source: mapped by CiteSpace. 
Through the analysis of the academic community, it can be seen that the current research on ESG is mainly concentrated in developed countries, such as those in Europe and the United States. However, the closeness of cooperation among scholars is not high and is relatively scattered. Therefore, ESG research is still in the development stage.

\subsubsection{Statistics of Research Hotspots on ESG}

Keywords abstract the core points of research in the field. This paper used CiteSpace software for keyword co-occurrence analysis, which can reveal the research hotspots of ESG in different periods and show the context and progress of ESG research.

In this paper, we used CiteSpace to analyze the co-occurrence of keywords, selected "Keyword" as the node type, and clustered the keywords to obtain the keyword cooccurrence map in Figure 3. As the result shows, modularity $=0.431$, which is greater than 0.3 , and therefore, the clustering structure is significant, while silhouette $=0.7421$, which is greater than 0.7, indicating that the results are plausible. Firstly, through the cluster analysis of co-keywords, it can be observed that the topics focus on happiness, transparency, shareholder value, organizational performance, corporate philanthropy, organization, and institutional theory. Secondly, from the analysis of word frequency, the top 10 most frequent keywords are corporate social responsibility (234 times), performance (140 times), sustainability (125 times), management (113 times), financial performance (83 times), firm (80 times), impact (80 times), social responsibility (80 times), governance (74 times), and strategy (71 times). All of these were concentrated between 2004 and 2007 (see Table 2). Lastly, ranking by centrality shows the importance of keywords in the co-occurrence network. In terms of keyword centrality, the research hotspots with high importance are concentrated on firm (0.16), behavior (0.13), impact $(0.12)$, strategy $(0.1)$, competitive advantage (0.09), corporate social responsibility (0.08), management (0.08), sustainability (0.07), governance (0.07), and organization (0.07) (see Table 3 ).

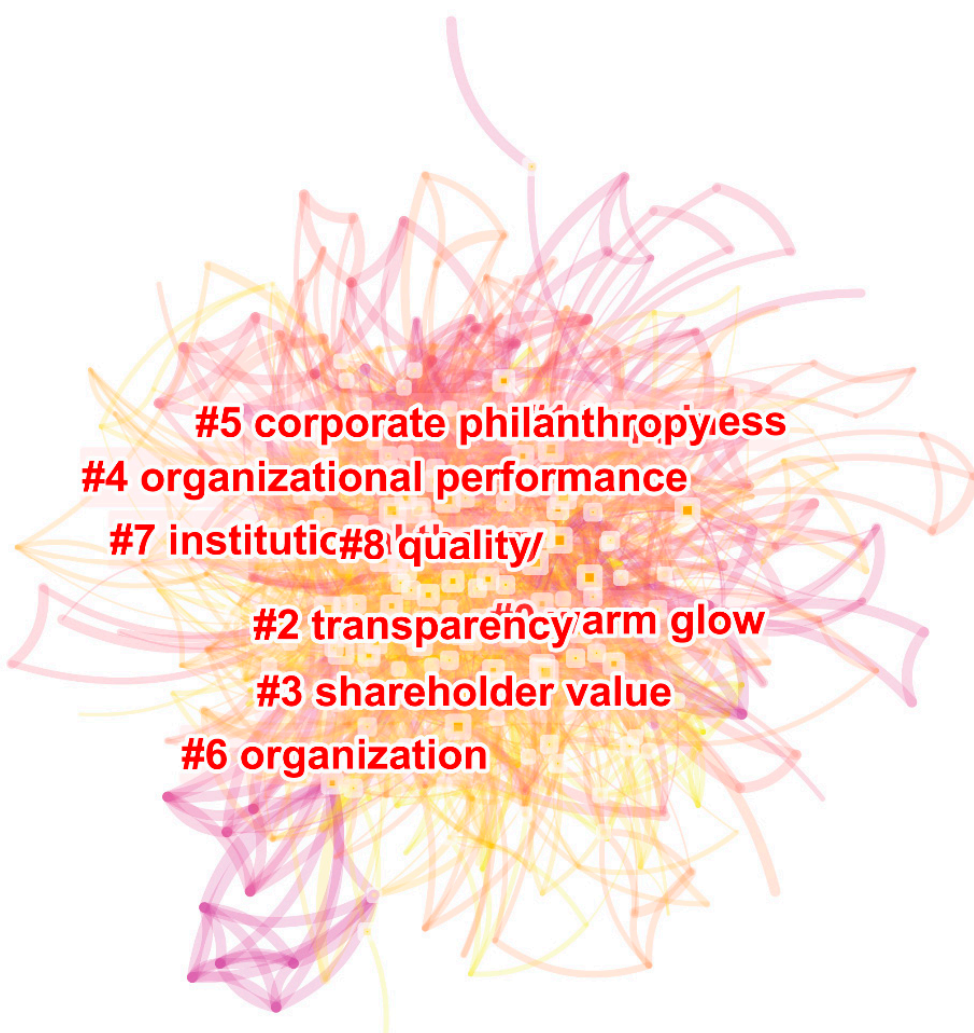

Figure 3. Keyword co-occurrence graph. Source: mapped by CiteSpace. 
Table 2. Statistic information of keywords (by frequency 1-50).

\begin{tabular}{|c|c|c|c|c|c|c|c|c|c|}
\hline No. & Freq & Centrality & Year & Keywords & No. & Freq & Centrality & Year & Keywords \\
\hline 1 & 234 & 0.08 & 2004 & $\begin{array}{l}\text { corporate social } \\
\text { responsibility }\end{array}$ & 26 & 22 & 0.04 & 2005 & green \\
\hline 2 & 140 & 0.06 & 2004 & performance & 27 & 22 & 0.03 & 2004 & company \\
\hline 3 & 125 & 0.07 & 2007 & sustainability & 28 & 21 & 0.01 & 2009 & reputation \\
\hline 4 & 113 & 0.08 & 2004 & management & 29 & 20 & 0.09 & 2004 & $\begin{array}{l}\text { competitive } \\
\text { advantage }\end{array}$ \\
\hline 5 & 83 & 0.06 & 2006 & $\begin{array}{c}\text { financial } \\
\text { performance }\end{array}$ & 30 & 20 & 0.06 & 2009 & construction \\
\hline 6 & 80 & 0.16 & 2004 & firm & 31 & 19 & 0.06 & 2008 & capability \\
\hline 7 & 80 & 0.12 & 2004 & impact & 32 & 19 & 0.04 & 2012 & determinant \\
\hline 8 & 80 & 0.06 & 2007 & social responsibility & 33 & 19 & 0.02 & 2016 & CSR \\
\hline 9 & 74 & 0.07 & 2006 & governance & 34 & 19 & 0.02 & 2007 & $\begin{array}{c}\text { stakeholder } \\
\text { theory }\end{array}$ \\
\hline 10 & 71 & 0.1 & 2007 & strategy & 35 & 18 & 0.03 & 2011 & $\begin{array}{c}\text { resource based } \\
\text { view }\end{array}$ \\
\hline 11 & 61 & 0.07 & 2005 & organization & 36 & 18 & 0.03 & 2009 & choice \\
\hline 12 & 61 & 0.06 & 2004 & model & 37 & 18 & 0.02 & 2012 & $\begin{array}{l}\text { corporate } \\
\text { governance }\end{array}$ \\
\hline 13 & 44 & 0.07 & 2006 & perspective & 38 & 17 & 0.06 & 2005 & industry \\
\hline 14 & 38 & 0.13 & 2004 & behavior & 39 & 17 & 0.03 & 2010 & competition \\
\hline 15 & 37 & 0.04 & 2007 & business & 40 & 16 & 0.04 & 2006 & environment \\
\hline 16 & 33 & 0.04 & 2005 & market & 41 & 16 & 0.03 & 2012 & ownership \\
\hline 17 & 33 & 0.02 & 2006 & responsibility & 42 & 16 & 0.02 & 2016 & $\begin{array}{c}\text { financial } \\
\text { performance }\end{array}$ \\
\hline 18 & 30 & 0.02 & 2010 & firm performance & 43 & 15 & 0.06 & 2006 & consumer \\
\hline 19 & 29 & 0.03 & 2011 & shareholder value & 44 & 15 & 0.02 & 2009 & information \\
\hline 20 & 29 & 0.03 & 2007 & innovation & 45 & 15 & 0.01 & 2015 & philanthropy \\
\hline 21 & 27 & 0.06 & 2008 & cost & 46 & 15 & 0 & 2016 & disclosure \\
\hline 22 & 27 & 0.04 & 2011 & identity & 47 & 14 & 0.02 & 2012 & work \\
\hline 23 & 27 & 0.03 & 2005 & legitimacy & 48 & 14 & 0.02 & 2010 & $\begin{array}{l}\text { environmental } \\
\text { performance }\end{array}$ \\
\hline 24 & 24 & 0.01 & 2013 & risk & 49 & 14 & 0.01 & 2017 & firm value \\
\hline 25 & 23 & 0.02 & 2011 & $\begin{array}{l}\text { institutional } \\
\text { theory }\end{array}$ & 50 & 14 & 0 & 2015 & self-regulation \\
\hline
\end{tabular}


Table 3. Statistic information of keywords (by centrality 1-50).

\begin{tabular}{|c|c|c|c|c|c|c|c|c|c|}
\hline No. & Freq & Centrality & Year & Keywords & No. & Freq & Centrality & Year & Keywords \\
\hline 1 & 80 & 0.16 & 2004 & firm & 26 & 19 & 0.04 & 2012 & determinant \\
\hline 2 & 38 & 0.13 & 2004 & behavior & 27 & 16 & 0.04 & 2006 & environment \\
\hline 3 & 80 & 0.12 & 2004 & impact & 28 & 13 & 0.04 & 2005 & framework \\
\hline 4 & 71 & 0.1 & 2007 & strategy & 29 & 9 & 0.04 & 2004 & consequence \\
\hline 5 & 20 & 0.09 & 2004 & $\begin{array}{l}\text { competitive } \\
\text { advantage }\end{array}$ & 30 & 29 & 0.03 & 2011 & shareholder value \\
\hline 6 & 234 & 0.08 & 2004 & $\begin{array}{l}\text { corporate social } \\
\text { responsibility }\end{array}$ & 31 & 29 & 0.03 & 2007 & innovation \\
\hline 7 & 113 & 0.08 & 2004 & management & 32 & 27 & 0.03 & 2005 & legitimacy \\
\hline 8 & 125 & 0.07 & 2007 & sustainability & 33 & 22 & 0.03 & 2004 & company \\
\hline 9 & 74 & 0.07 & 2006 & governance & 34 & 18 & 0.03 & 2011 & $\begin{array}{l}\text { resource based } \\
\text { view }\end{array}$ \\
\hline 10 & 61 & 0.07 & 2005 & organization & 35 & 18 & 0.03 & 2009 & choice \\
\hline 11 & 44 & 0.07 & 2006 & perspective & 36 & 17 & 0.03 & 2010 & competition \\
\hline 12 & 140 & 0.06 & 2004 & performance & 37 & 16 & 0.03 & 2012 & ownership \\
\hline 13 & 83 & 0.06 & 2006 & $\begin{array}{c}\text { financial } \\
\text { performance }\end{array}$ & 38 & 12 & 0.03 & 2005 & quality \\
\hline 14 & 80 & 0.06 & 2007 & $\begin{array}{c}\text { social } \\
\text { responsibility }\end{array}$ & 39 & 12 & 0.03 & 2008 & knowledge \\
\hline 15 & 61 & 0.06 & 2004 & model & 40 & 11 & 0.03 & 2009 & response \\
\hline 16 & 27 & 0.06 & 2008 & cost & 41 & 10 & 0.03 & 2015 & social movement \\
\hline 17 & 20 & 0.06 & 2009 & construction & 42 & 9 & 0.03 & 2006 & product \\
\hline 18 & 19 & 0.06 & 2008 & capability & 43 & 7 & 0.03 & 2006 & alliance \\
\hline 19 & 17 & 0.06 & 2005 & industry & 44 & 6 & 0.03 & 2005 & commitment \\
\hline 20 & 15 & 0.06 & 2006 & consumer & 45 & 33 & 0.02 & 2006 & responsibility \\
\hline 21 & 7 & 0.06 & 2006 & altruism & 46 & 30 & 0.02 & 2010 & $\begin{array}{c}\text { firm } \\
\text { performance }\end{array}$ \\
\hline 22 & 37 & 0.04 & 2007 & business & 47 & 23 & 0.02 & 2011 & $\begin{array}{l}\text { institutional } \\
\text { theory }\end{array}$ \\
\hline 23 & 33 & 0.04 & 2005 & market & 48 & 19 & 0.02 & 2016 & CSR \\
\hline 24 & 27 & 0.04 & 2011 & identity & 49 & 19 & 0.02 & 2007 & $\begin{array}{l}\text { stakeholder } \\
\text { theory }\end{array}$ \\
\hline 25 & 22 & 0.04 & 2005 & green & 50 & 18 & 0.02 & 2012 & $\begin{array}{l}\text { Corporate } \\
\text { governance }\end{array}$ \\
\hline
\end{tabular}

Source: own elaboration based on CiteSpace.

\subsubsection{Statistics of Research Trend on ESG}

The burst terms indicate that the frequency of a keyword sharply increases within a certain period of time. When the frequency of a keyword becomes higher, its importance also increases. That is, burst terms can reveal the research hotspot and navigate the research direction in a field in a designated timeframe. In this paper, CiteSpace is used for the analysis of burst terms, and 19 burst terms were obtained. As can be observed, in terms of the intensity of keywords, the focus of research is financial performance, philanthropy, company, self-regulation, framework, technology, firm value, competition, perspective, and organization. By contrast, over the past five years, the focus was on financial performance, philanthropy, self-regulation, firm value, and director. In terms of trends, ESG research 
tends to focus on the interaction between the organizational level and social responsibility of companies and related research (see Table 4).

Table 4. Statistic information of burst terms.

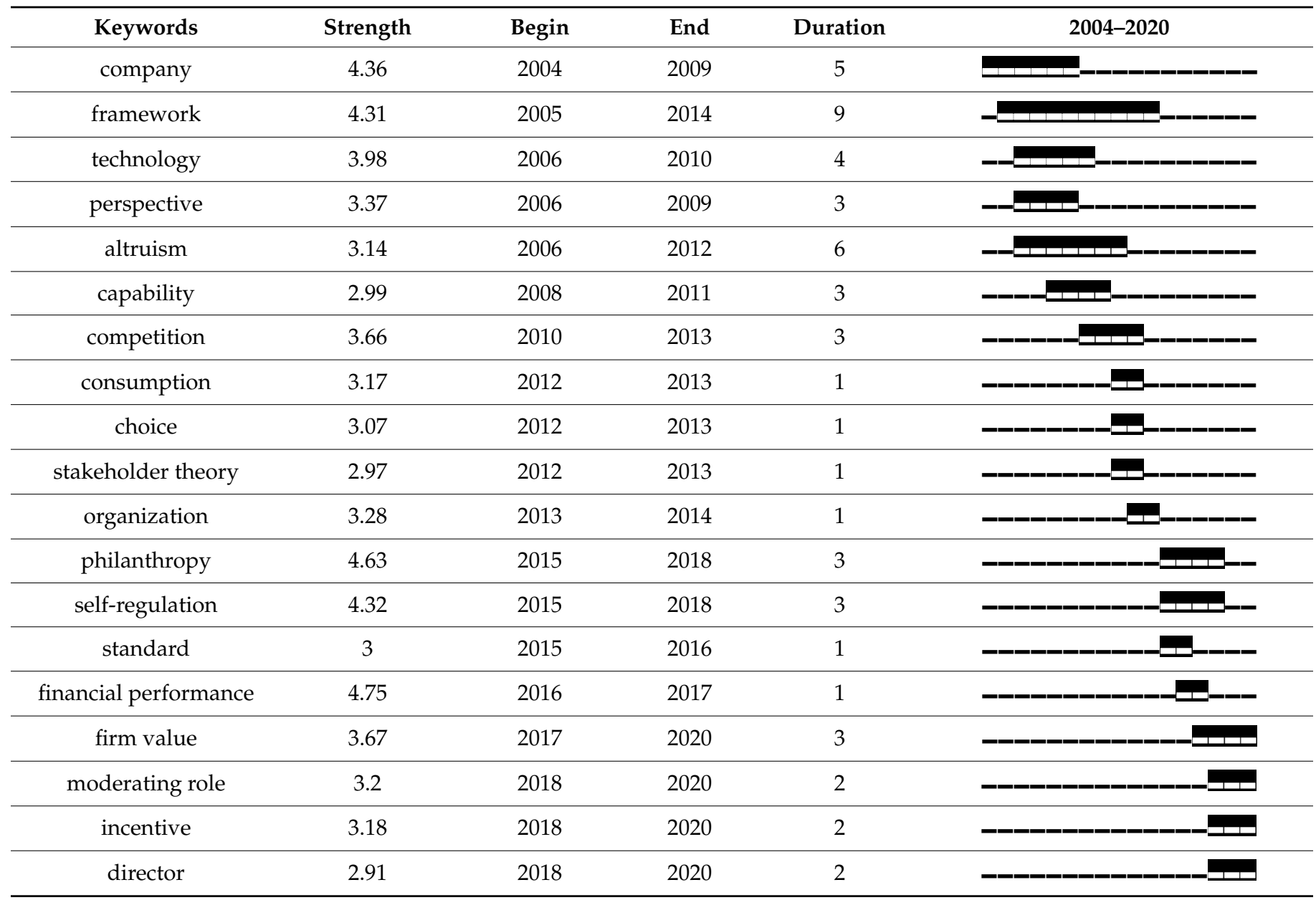

Source: own elaboration base on CiteSpace. Note: In the last column, the bold part means the duration.

From the statistical results of CiteSpace, some characteristics and regularities of ESG research can be observed. Firstly, ESG research mainly focuses on the topics of happiness, shareholder value, organizational performance, corporate philanthropy, transparency, organization, and institutional theory (see Figure 3). Secondly, it can be observed from the statistical results of keywords and burst terms that ESG research focuses on detailed exploration of the three dimensions of environmental, social, and governance, while the research taking ESG as a whole does not show an obvious trend.

\subsection{Analysis of Research Progress in ESG}

This subsection presents the analysis of the research progress of ESG according to the importance, frequency, and attention of research hotspots based on the statistical results of ESG research hotspots and research trends combined with a systematic literature review.

\subsubsection{The Theoretical Basis of ESG}

The theoretical basis is the cornerstone of academic research. From the results of the keyword co-occurrence map (see Figure 3), keyword statistics (see Tables 2 and 3), and burst terms statistics (see Table 4), it can be observed that the theoretical basis of ESG research mainly focuses on institutional theory and stakeholder theory.

In terms of institutional theory, Chatterji and Toffel (2010) explained the impact of ESG rating on improving environmental performance [12], Jayachandran et al. (2013) demonstrated the impact of social performance on corporate performance [13], Koh et al. 
(2014) studied the risk prevention role played by ESG [14], and Flammer et al. (2019) studied the binding effect of social responsibility contracts on executives [15]. In general, ESG research discusses the role of the legitimacy behavior of corporate in the sustainable development of a company based on institutional theory.

In terms of stakeholder theory, Kölbel et al. (2017) studied the relationship between corporate social irresponsibility and financial risk [16], Surroca et al. (2010) studied the relationship between corporate responsibility and financial performance [17], Muller and Kräussl (2011) studied the relationship between corporate charitable donations and return on investment [18], and Flammer and Kacperczyk (2019) explored the impact of ESG practice on employee management [19]. In general, based on stakeholder theory, ESG research suggested that enterprises that respond better to the ESG requirements of stakeholders will perform better than irresponsible enterprises.

2.4.2. The Interaction between the Environmental (E), Social (S), and Governance (G) Dimensions

The three factors of ESG are of great significance for the operation and sustainable development of enterprises. It can be observed from the results of quantitative analysis in this paper that the current research on ESG is mainly based on the environmental (E), social $(\mathrm{S})$, and governance $(\mathrm{G})$ dimensions. At the same time, through our systematic literature review, it can be observed that there are a considerable number of studies on the interaction between E, S, and G. Therefore, this paper systematically summarizes the research on the interaction between the environmental (E), social (S), and governance $(G)$ dimensions.

\section{Interaction Research of Environmental (E) Dimension}

The environment has always been a central problem occupying academia's concerns. The environmental (E) dimension in ESG research mainly regards the interaction between the environmental $(E)$ and governance $(G)$ dimensions. In the research on the interaction between the environmental (E) and governance $(\mathrm{G})$ dimensions, the related keywords are management, governance, green, environment, and environmental performance. The frequencies of the keywords are, respectively, $113,74,22,16$, and 14, and they all rank in the top 48 (see Table 2). The centrality of the first four keywords is, respectively, 0.08, 0.07, 0.04, and 0.04 , and they all rank in the top 27 (see Table 3). Therefore, the interaction between the environmental $(E)$ and governance $(\mathrm{G})$ dimensions is a hot spot of ESG research.

First, from the perspective of executive factors, Flammer et al. (2019) found that the CSR contract drives the attention of executives to stakeholders, which can improve the corporate governance and its impact on society and the environment in the long run. Thus, integrating the environment and social performance into senior executive compensation is of great importance [15]. Davidson et al. (2019) found that enterprises led by nonmaterialistic CEOs have good performance in social responsibility, such as their treatment of the environment, and this is positively correlated with stock price performance [20].

Second, from the perspective of stakeholder factors, Cheng et al. (2014) pointed out that the excellent performance of corporate social responsibility strategies will bring better financing channels. Specifically, the improvement in the participation of stakeholders reduces the agent cost, and the increased transparency reduces the information asymmetry, so the performance of social responsibility is negatively correlated with capital constraint, leading to better financing channels. The environmental dimension is one of the factors that promotes this relationship [21].

Among the studies mentioned in this paper, there is little research on the interaction between the environmental (E) and social (S) dimensions, because the environmental (E) dimension is usually attributed to the social (S) dimension in measurements and research.

\section{Interaction between the Social (S) and Governance (G) Dimensions}

From the ranking of word frequency and centrality of keywords, it can be seen that the research hotspots of ESG focus on the social (S) and governance (G) levels. In the interactive relationship between the social (S) and governance (G) dimensions, the related keywords 
include corporate social responsibility, management, social responsibility, governance, organization, behavior, responsibility, shareholder value, identity, capability, stakeholder theory, corporate governance, and ownership. The frequencies are, respectively, 234, 113, $80,74,61,38,33,29,27,19,19,18$, and 16, and they all rank in the top 41 (see Table 2). In addition, their centrality degrees are, respectively, $0.08,0.08,0.06,0.07,0.07,0.13,0.02,0.03$, $0.04,0.06,0.02$, and 0.02 , and they all rank in the top 50 (see Table 3). Therefore, in terms of either word frequency or importance, research on the interaction between the social (S) and governance $(\mathrm{G})$ dimensions is a hot topic. A large number of studies on the interaction between them are also presented in the literature review.

Combing the bibliometrics analysis results and the systematical literature review, this study suggests that the interaction between the social (S) and governance $(\mathrm{G})$ dimensions mainly focuses on the interaction between the social (S) dimension and executives and the interaction between the social (S) dimension and stakeholders.

\section{(1) The Social (S) Dimension and Executive Factors}

From the statistical results of the burst terms, it can be observed that the keyword represented by "director" has been the focus of attention at the governance $(G)$ level in recent years (see Table 4). Secondly, among the above high-frequency words, management, governance, behavior, identity, capability, corporate governance, and ownership are closely related to executive factors. Therefore, this paper first addresses the interaction between the social (S) dimension and executive factors.

(1) The Impact of the Social (S) Dimension on Executive Factors

The role of social responsibility in corporate governance is first reflected in the impact of the social (S) dimension on executive factors. Kim et al. (2012) found that senior executives practicing CSR are unlikely to be investigated by the SEC regarding violations of GAAP, because social responsibility can play an important role in constraining earning management, making enterprises more conservative in accounting and business decision making; provide more transparent financial information; and encourage executives to produce high-quality financial reports [22]. Gao et al. (2014) found a significant negative correlation between social good and insider trading of senior executives, because the social responsibility image can be used as a governance mechanism to restrict self-interest behaviors, such as insider trading [23]. Hubbard et al. (2017) studied social responsibility investment and the possibility of CEOs being dismissed. The results show that when financial performance is poor, more investment in corporate social responsibility will increase the possibility of CEOs being dismissed. Moreover, when financial performance is good, the possibility of CEOs being dismissed will be reduced. Hence, social responsibility activities have an essential effect on CEOs [24].

(2) The Impact of Executive Factors on the Social (S) Dimension

It cannot be overemphasized how important the role of senior management is in determining the future and operation of a company. This explains why they are able to affect the realization of social responsibility. For instance, studies by Fu et al. (2020) concluded that the chief sustainability officer (CSO) has an impact on the social performance of a company and that the creation of a CSO position can increase the socially responsible activities of a company while reducing the chances of irresponsible behavior occurring. Moreover, the presence of a CSO position has a greater impact on reducing irresponsible corporate behavior. This especially occurs when the company is part of a controversial or condemned industry [25]. Notably, the personal traits, behaviors, and characteristics of the $\mathrm{CEO}$, who possesses the lifeblood of the company, will greatly impact what a company will do and how far it will go in taking social responsibility.

Regarding the traits of CEOs, Tang et al. (2015) found that a CEO's arrogance is negatively correlated with corporate social responsibility behavior but positively correlated with corporate social irresponsibility behavior. However, the relationship between a CEO's arrogance and corporate social irresponsibility diminishes when companies rely more on stakeholders for resources and external markets become more uncertain or competitive in the marketplace [26]. Petrenko et al. (2016) found that a leader's concern for personal 
image and the need to enhance it are associated with social responsibility. CEOs being narcissistic has a positive impact on the level and image of corporate social responsibility [27]. Tang et al. (2018) examined the different roles and effects of narcissistic and arrogant CEOs on corporate social responsibility. The research shows that narcissistic and arrogant CEOs hold different attitudes about how many social responsibility activities their companies should undertake. Narcissistic CEOs show more concern about social responsibility than arrogant CEOs do. Further research carried out on this topic showed that the positive relationship between CEOs with narcissistic traits and social responsibility activities is reinforced when peer firms invest less in social responsibility activities than in the firms that they run. Under the same conditions, the negative relationship between the arrogant $\mathrm{CEO}$ and social responsibility activities has been strengthened [28]. In addition, Davidson et al. (2019) studied the impact of CEO materialism on corporate social responsibility performance. The research used data from the KLD database to calculate corporate social responsibility scores and found that companies led by materialistic CEOs had more "weaknesses" than "strengths," which rendered a lower score on social responsibility. In contrast, the social responsibility performance of companies led by non-materialistic CEOs in terms of environment, diversity, and product safety can positively influence the stock price of the company and the positive relationship between the "strengths" of corporate social responsibility and profitability. Thus, CEOs who seek material benefits are more likely to invest in social responsibility activities with a desire to increase their interests, while CEOs who are non-materialistic have the goal of increasing their shareholder value [20].

In terms of CEOs' values and political ideologies, it is suggested that the fair market ideology, as a psychological antecedent influencing the beliefs and moral feelings of senior executives, influences the moral values and feelings of individuals. Specifically, senior executives with business, economics, and legal educational backgrounds show a higher degree of participation in social responsibility. This is because their educational backgrounds lead to their belief in the relationship between corporate social performance and corporate financial performance, which is derived from the fair market ideology (Hafenbrädl and Waeger, 2017) [29]. In addition, in terms of the research on the relationship between political ideology and social responsibility, Chin et al. (2013) found that liberal CEOs pay more attention to social responsibility compared to those who believe in conservatism. When CEOs have more power, their political liberalism regarding social responsibility will be amplified. Meanwhile, the recent financial performance of the enterprise will have less of an impact on the action of liberal CEOs in the aspect of social responsibility [30]. Furthermore, Gupta et al. (2019) pointed out that liberal CEOs are more likely to carry out social responsibility activities. Moreover, they suggested that the extroversion and narcissism characteristics of CEOs will amplify the relationship between liberal ideology and social responsibility [31]. After research on the influence mechanism of CEOs' liberal ideology on social responsibility commitment, Gupta et al. (2021) studied how CEOs' ideology affects their peers' appointment of senior positions in relation to social responsibility. It was observed that, compared with liberal CEOs, when conservative CEOs set up senior executive positions related to CSR, other companies were more likely to follow suit [32]. Moreover, such senior executive positions will have a positive impact on corporate social responsibility (Fu et al., 2020) [25].

In terms of CEO demographic variables, the age of the CEO is also an important factor affecting corporate social responsibility activities because of the characteristics of large investment and the slow effect of social responsibility investment. Kang's (2016) research showed that $C E O$ s due for retirement have a negative effect on social responsibility commitment. However, this negative effect will weaken when they retire at a relatively old age or they retain their positions in the BOD [33]. Furthermore, where CEOs come from is a notable factor influencing their strategic decision-making styles. Notably, local CEOs appear to make decisions that will benefit long-term growth by paying more state taxes and being more socially responsible when compared with non-local CEOs. Hence, choosing local CEOs is more likely to control the phenomenon of short-termism in management 
(Lai et al., 2020) [34]. Similarly, from the perspective of social identity theory, Bertrand et al. (2021) observed that when a local firm hires a non-local CEO, the firm needs to demonstrate better performance in social responsibility practices and social performance levels to increase its legitimacy and credibility in response to bias and pressure from the outside, as a non-local CEO is perceived as an external leader by local stakeholders [35].

In addition to the direct effect of the above-mentioned senior executive factors on social responsibility, the influence of senior executive governance on social responsibility will also occur via other factors. Church et al. (2019) studied how the measurement basis (financial or non-financial) affects the decision-making behavior of middle and senior managers in social responsibility projects. The research found that when executives favor corporate social responsibility, the level of social responsibility investment based on the non-financial measurement is higher than that based on financial measurement. Moreover, executives who support corporate social responsibility investment invest more based on financial and non-financial measurement than based on financial measurement only. Thus, non-financial measures increase the social attention of executives who support corporate social responsibility, while social attention regulates their investment decisions in turn [36]. In addition, Han et al. (2019) researched whether studying or training abroad will affect the corporate social responsibility practice of private enterprises. It was found that enterprises operated by executives with backgrounds of studying abroad show a higher social responsibility performance level than that of enterprises led by local executives [37]. Luo et al. (2021) studied how executives with backgrounds of studying or working abroad in the BOD influence social responsibility according to the data of listed companies in China from 2000 to 2012. It can be observed that the existence of these returners has largely improved these enterprises' participation in social responsibility, especially in the form of corporate donations [38]. In addition, $\mathrm{Li}$ and $\mathrm{Lu}(2020)$ developed a dual mechanism model containing public agents (government officials) and private agents (CEOs) based on "China's 12th Five Year Plan" to study under what circumstances enterprises will respond to the government initiative by increasing social responsibility. The research showed that it is more likely for enterprises to take more CSR actions to respond to government initiatives when the CEO has a greater interest in legitimacy. Specifically, CEOs are more likely to take social responsibility actions when their tenure as a CEO is relatively short, and they need legitimacy by building credibility. Thus, corporate social responsibility is an action taken by CEOs to respond to external stress [39].

(2) The Social (S) Dimension and Stakeholder Factors

From the statistical results of the burst terms, it can be seen that the keywords represented by "stakeholder theory" and "incentive" are the focus of attention at the governance (G) level (see Table 4). Secondly, the high-frequency words related to governance $(G)$ include management, governance, organization, behavior, shareholder value, identity, capability, stakeholder theory, and ownership, which are closely related to stakeholder factors (see Table 2). The participation of stakeholders is the key to ESG practice. Whether these stakeholders can bring benefits to the enterprises through social responsibility activities depends on whether these social responsibility activities can attract the attention of stakeholders; namely, whether these social responsibility activities are valued by the stakeholders (Madsen and Rodgers, 2015) [40]. Research on the relationship between social responsibility practice and stakeholders is mainly concentrated on the interaction between the social (S) dimension and employees and the interaction between the social (S) dimension and investors.

(1) The Impact of the Social (S) Dimension on Stakeholder Factors

Regarding the incentive effects for employees, Flammer and Luo (2015) found that social responsibility can contribute to motivating employees and improving their workplace behavior as an employee governance tool [41]. Moreover, Balakrishnan et al. (2011) pointed out that employees' contributions to enterprises will significantly increase with the improvement in the enterprise donation level. Thus, social responsibility activities serve as effective leverage to motivate employees to contribute for themselves and the 
organization [42]. In addition, Carnahan et al. (2017) researched the relationship between social responsibility investment and employee retention. They found that due to the value preference of employees for meaningful work, the social responsibility practice of enterprises may provide employees with more retention willingness [43]. Moreover, in regard to the impact of social responsibility activities on human resource management, Farooq et al. (2017) studied the relationship between social responsibility and employee attitude and behavior. Their research showed that social responsibility activities focusing on employee welfare may enhance perceived respect and further affect the organizational identification of employees [44].

Regarding investors, Elliott et al. (2014) studied the relationship between corporate social responsibility performance and investors' assessment. It was observed that there is an unexpected causality between corporate social responsibility performance and investors' assessment of basic value, and investors' explicit assessment of the corporate social responsibility performance will weaken this relationship. The impact of investors without a clear assessment of corporate social responsibility performance is unintentional, because they inadvertently use their emotional response to corporate social responsibility performance to estimate the basic value [45]. Hence, it is important to assess corporate social responsibility (with an index or evaluation system), since it can affect the investment decision of investors.

(2) The Impact of Stakeholder Factors on the Social (S) Dimension

Regarding employees and the practice of social responsibility, employees exert a significant influence on social responsibility as an important component of enterprises. Muller et al. (2014) found that employees serve as a vital driving force for the charitable efforts of enterprises, whose motivation may function through psychological factors such as compassion [46]. Gupta et al. (2017) explained how the political beliefs of organizational members shape the performance of social responsibility from a more detailed entry point, from the perspective of organizational politics. The employee donations to the two major political parties in the United States are considered a new measure of organizational political ideology. The results show that enterprises with liberal employees are more engaged in social responsibility activities than those with conservative employees. Therefore, social responsibility activities may be shaped by the values of employees in the organization [47].

Investors also play an important role in the practice of social responsibility. Mun and Jung (2018) pointed out that overseas institutional investors and local corporate social responsibility experts impact the practice of social responsibility, mainly reflected in the increase in the number of women in the BOD and management positions [48]. Naughton et al. (2019) found that investors' sentiments toward social responsibility activities change with time, and their sentiments can exert some influence on the corporate social responsibility commitment [49].

\subsubsection{The Impact of ESG on Economic Consequences}

In general, the ESG performance index is likely to clarify the relationship between sustainable investment and financial performance (Khan et al., 2016) [50]. According to CiteSpace's statistics on keywords, from the perspective of word frequency (see Table 2) and centrality (see Table 3), related keywords include corporate social responsibility, performance, sustainability, financial performance, social responsibility, responsibility, firm performance, shareholder value, and firm value, and their frequency of occurrence is 234, $140,125,83,80,33,30,29$, and 14 , respectively. In terms of centrality, except for firm value, the centrality of the other eight keywords is $0.08,0.06,0.07,0.06,0.06,0.02,0.02$, and 0.03 , respectively. It can be observed that the related keywords rank top in terms of word frequency and centrality. In terms of time, "financial performance" was a research hotspot in 2006 and 2016. Moreover, "firm performance" and "firm value" became hot topics in 2010 and 2017, respectively. In addition, from the statistical results of the burst terms, the keywords represented by "financial performance" and "firm value" attracted much attention between 2016 and 2020 (see Table 4). Therefore, the research on the relationship 
between ESG and economic consequences is a hot topic. For example, Awaysheh et al. (2020) used the KLD database to measure the overall situation of ESG. They studied the benchmarking of enterprises in the fixed effect of time and industry, identifying the best (top 10\%) and worst enterprises (last 10\%). It was found that the best enterprises have a higher level of operating performance and a higher relative market valuation than those of their peers. When the governance $(G)$ dimension is removed, the result remains unchanged [51]. Research on the relationship between corporate social irresponsibility and financial risks showed that the negative media coverage on the environmental, social, and governance (ESG) issues will increase the credit risks of enterprises and lead to an increase in enterprise financial risks (Kölbel et al., 2017) [16]. Moreover, different scholars measure the sustainable development behavior of enterprises from different perspectives, which can be divided into four types, namely, positive correlation, negative correlation, non-linear relationship, and indirect relationship.

\section{Positive Correlation}

First, most of the existing studies on this topic measure ESG activities from the perspective of the combination of the environmental (E) and social (S) dimensions and empirically test the relationship between ESG activities and corporate financial performance and corporate value. Mackey et al. (2007) used the KLD database and concentrated on the environmental (E) and social (S) dimensions, believing that there is a positive correlation between ESG activities and corporate values [52]. Jayachandran et al. (2013) studied the impact of corporate social performance (CSP) on corporate performance. The results of the study using the classification measures of the social dimension (product social performance) and environmental dimension (environmental and social performance) show that compared with the environmental (E) dimension, the social (S) dimension has a stronger, positive impact on corporate performance [13]. In addition, Flammer et al. (2019) studied the effectiveness and implications of integrating environmental and social performance standards into executive compensation. It was found that the contract not only alleviated the myopia of enterprises but also improved corporate performance and corporate value significantly, which indicates the increase in long-term operating profit. Moreover, enterprises using the contracts improve their environmental and social performance, especially in the environment and local communities [15].

Secondly, we reviewed the studies that only focus on the environmental (E) dimension. Environmental social performance has a positive impact on corporate performance (Jayachandran et al., 2013) [13], but environmental screening conditions reduce corporate financial performance (Barnett and Salomon, 2006) [53]. Matsumura et al. (2014) studied the impact of carbon emissions and voluntary disclosure of carbon emissions on corporate value by collecting environmental performance data. It was found that carbon emissions are inversely proportional to corporate value and that the decision and level of managers' disclosure of carbon emissions are directly proportional to corporate value [54].

Finally, we also reviewed the studies that only focus on the social (S) dimension. Godfrey (2005) studied the relationship between philanthropic activities and shareholder wealth and concluded that corporate philanthropy could generate positive moral capital between communities and stakeholders. This kind of moral capital could provide shareholders with an insurance-like mechanism of intangible values based on corporate relationships. This protective mechanism could also help to increase shareholders' wealth [55]. Wang and Qian (2011) researched the relationship between corporate philanthropy and corporate financial performance. Corporate philanthropy is expected to have a positive impact on corporate financial performance because it helps companies to gain socio-political legitimacy, thereby enabling companies to receive positive stakeholder responses and gain political opportunities. For companies with a higher public profile and companies with better past performance, the relationship between positive philanthropy and performance is stronger because of a more positive response from stakeholders to the philanthropy of these companies. However, private companies or companies with no political connections can benefit more from philanthropy because obtaining access to political resources is criti- 
cal. Therefore, researchers believe that corporate philanthropy could improve corporate financial performance by stimulating a positive response from key stakeholders, such as employees, customers, and investors, and by obtaining political resources from the government [56]. Furthermore, Kaul and Luo (2018) studied the conditions for corporate social responsibility to provide positive benefits to the company, and found that if social responsibility is related to a company's core business or does not overlap with non-profit activities, it can provide financial benefits to the company [57].

\section{Negative Correlation}

There is a negative relationship between ESG activities and economic consequences. The research conducted by Manchiraju and Rajgopal (2017) showed a significant negative correlation between corporate social responsibility and shareholder value [58]. Similarly, the research conducted by Chen et al. (2018) found that the mandatory disclosure of corporate social responsibility not only reduces performance but also increases social responsibility costs, which generate positive externalities at the expense of shareholders' interests [59].

\section{Non-Linear Relationship}

There are studies that show that the relationship between corporate sustainable development behavior and financial performance is not linear. For example, the study conducted by Barnett and Salomon (2006), which analyzed the relationship between social performance and financial performance based on environmental (E) and social (S) dimensions, found that financial returns began to decline as the number of social $(\mathrm{S})$ dimensional screening projects used by socially responsible investment increased. However, the financial returns rebounded again as the number of screenings continued to increase. In other words, the study found a curve relationship [53]. Furthermore, Barnett and Salomon (2012) found a U-shaped relationship between corporate social performance and corporate financial performance. Specifically, companies with low CSP have higher financial performance than those with medium CSP, but companies with high CSP have the highest financial performance. That is, the companies with the highest CSP usually have the highest financial performance [60]. Moreover, Zhao and Murrell (2016) pointed out that corporate social performance may not have a positive impact on corporate financial performance. On the contrary, there is a complex relationship between corporate social performance and corporate financial performance, so it cannot be simply said that doing good will do well [61].

\section{Indirect Relationship}

Surroca et al. (2010) found that there is no direct relationship between corporate social responsibility and financial performance. Instead, mediating factors, such as innovation, human capital, reputation, and culture, are required to form an indirect relationship [17]. The research conducted by Hull and Rothenberg (2008) found that supporting innovation and the level of industry differences are factors that could regulate the positive relationship between corporate social performance and financial performance [62]. Ramchander et al. (2012) discovered the role of information asymmetry in explaining the relationship between corporate social responsibility and financial performance [63]. Similarly, the research conducted by Lys et al. (2015) found that the positive correlation between corporate performance and corporate social responsibility expenditure is more likely to be due to the signal of corporate social responsibility expenditure [64]. Later, Hawn and Ioannou (2016), on the basis of the neo-institutional theory, suggested that corporate social responsibility is related to better market value by distinguishing between external and internal corporate social responsibility actions [65]. Furthermore, Surroca et al. (2020) found that companies are facing tremendous pressure to achieve short-term goals in a free market economy, especially when companies participate in internally oriented corporate social responsibility projects and the combination of managerial entrenchment provisions (MEPs) and corporate social responsibility creates shareholder value. However, the combination of managerial entrenchment provisions (MEPs) and corporate social responsibility will destroy shareholder value when corporate social responsibility is externally oriented [66]. 
Among the studies reviewed in this paper, few use governance $(G)$ as a measurement dimension to study the impact of ESG on corporate financial performance or corporate value. The reason for this is that the influencing factors of the economic consequences of a company should be a comprehensive manifestation of multiple dimensions. Although the corporate governance structure could have an impact on it, a separate corporate governance structure has little significance for the economic consequences of a company.

\subsubsection{The Risk Prevention Role of ESG}

As a kind of non-financial investment of enterprises, ESG is a mechanism and means of risk prevention for enterprises. According to the analysis results of CiteSpace regarding keywords, from the word frequency results (see Table 2), the frequency of sustainability, strategy, legitimacy, risk, institutional theory, reputation, and competitive advantage is 125 , $71,27,24,23,21$, and 20, respectively, ranking in the top 29. From the results of centrality (see Table 3), the centrality of strategy, competitive advantage, sustainability, legitimacy, and institutional theory is $0.1,0.09,0.07,0.03$, and 0.02 , respectively, ranking in the top 47. It can be seen that ESG practice can meet the legitimate needs of stakeholders in the process of the sustainable development of enterprises. It can not only improve the social reputation of enterprises, but also play a role in resisting risks as a means of competition. Therefore, the risk prevention role of ESG in business activities is a research hotspot.

With regard to the ESG as a whole. Koh et al. (2014) took ESG as a whole as their research object and put forward the viewpoint of risk management. The authors used the KLD database to standardize multiple dimensions of community relations, diversity, employee relations, environment, and products and constructed an overall measurement index of corporate social performance. It is believed that social performance can be used as an insurance mechanism that is more valuable to companies with higher litigation risks [14]. Mithani (2017) found that philanthropy can alleviate the liability of foreignness (LOF) of companies after disasters in a specific country and can strengthen the position of multinational companies. Therefore, philanthropy has important strategic significance for multinational companies after disasters [67]. Zhou and Wang (2020) found that the fulfillment of corporate social responsibilities by subsidiaries can be used as a means to buffer the negative spillover effects caused by the parent company's reputation risk. Specifically, the social responsibility activities of subsidiaries could help them to obtain social legitimacy and form an insurance-like mechanism [68].

With regard to the environmental (E) dimension. Flammer (2013) researched the response of the stock market to environmental social responsibility and found that the active participation of enterprises in environmental aspects can create new competitive resources for companies and play an insurance-like role. On the one hand, shareholders will respond positively to companies that announce eco-friendly initiatives. Conversely, a company's environmental social responsibility will play an insurance-like role when an eco-harmful event occurs, thereby allowing the enterprise to suffer fewer losses [69].

With regard to the social (S) dimension. Shiu and Yang (2017) measured the social dimension through the KLD database and found that corporate social responsibility can play an insurance-like role in the negative events of stock and bond prices. This role can have a great impact on the first negative event [70]. Similarly, Jia et al. (2020) studied whether corporate social responsibility investment could be used as an insurance mechanism for corporate risk prevention. Specifically, when companies face higher external risks brought about by Reg SHO, pilot companies will pursue corporate social responsibility to obtain an insurance-like protective effect to reduce their short positions. Secondly, companies facing the threat of short-selling can increase their corporate social performance by addressing the "concerns" item of corporate social responsibility to deal with the short-selling threat. Finally, the increased corporate social responsibility will reduce the short equity of the pilot company's stocks. This decrease is attributed to the insurance effect of corporate social responsibility [71]. 
With regard to the governance $(\mathrm{G})$ dimension. Gao et al. (2014) used the KLD database to exclude the governance $(\mathrm{G})$ dimension to construct a corporate social responsibility net score and found the significant negative relationship between social good and insidetrading of executives [23]. Flammer and Kacperczyk (2019) found that using corporate social responsibility as a strategic tool to address the threat of knowledge encroachment from competitors can not only reduce the tendency of employees to join competing companies, but also decrease the possibility of valuable information leakage, even if employees join competing companies [19]. In a recent study, Bertrand et al. (2021) focused on the social pillar scores in the ESG scores of the Thomson Reuters ASSET4 database. It was observed that CEOs can improve corporate social responsibility practices and corporate social performance to respond to biases from outside when local companies have a foreign CEO [35].

\subsubsection{ESG Measurement}

ESG measurement is the basis for testing the effectiveness of enterprise ESG practice and the standard for enterprise ESG disclosure. The analysis results of CiteSpace showed that the centrality of the keyword "framework" in 2005 was 0.04 (see Table 3). Moreover, from the statistical results of the burst terms (see Table 4), the intensity of "framework" was 4.31. It was a keyword that received widespread attention in ESG research from 2005 to 2014, which is consistent with the rise of ESG research. A reasonable ESG framework is the basis for its measurement. Secondly, according to the term frequency of keywords (see Table 2), the word "disclosure" appeared most frequently in 2016, at 15 times. From the perspective of ESG development, the establishment of the ESG evaluation system promotes the rise of research issues related to ESG disclosure. Based on this, we summarized the measurement methods of ESG. In the selected literature in this paper, the data for measuring ESG overall or each dimension index score mainly originated from the KLD database and Thomson Reuters ASSET4 database. This study organized the advantages and disadvantages, measurement methods, and score construction based on the two databases in the literature (see Table 5).

\section{Measurement based on KLD Database}

In terms of ESG measurement, Kim et al. (2021) proposed a practical technique to evaluate corporate social responsibility policies [72], that is, to quantify corporate social responsibility insurance mechanisms. However, managers, investors, and researchers know little about whether these ratings measure corporate social responsibility accurately (Chatterji et al., 2016) [73]. The most widely used database in the literature is the KLD database, which can provide data relating to sustainable development. It is the most widely used database in previous studies on ESG (Shiu and Yang, 2017) [70], corporate social responsibility (Deckop et al., 2006) [74], corporate commitment to social good, the measurement of CSR performance (Gao et al., 2014) [23], and the relationship between social responsibility and financial performance (Ioannou and Serafeim, 2015) [75].

KLD is widely used because it has the following advantages. First, the KLD database covers a wide range of industries and a long-time frame. The database was built in 1991, and the total number of companies it has tracked since 2003 has reached 3100. Other databases with sustainability data, such as Thomson Reuters ASSET4, have shorter time series and cover fewer US companies. Second, the KLD database provides relevant information in a standardized form. It rates important attributes of corporate social performance and uses a set of objective evaluation standards to ensure the consistency of evaluation. Third, the KLD database is used by professional investment personnel to construct investment portfolios and is a comprehensive data source for tracking corporate social performance.

The research and ratings of ESG include the environmental, social, and governance (ESG) factors, using a proprietary research method to evaluate the ESG performance of companies. Before 2001, there were 33 projects in the KLD database, and this number had increased to 40 projects by 2007 (Shiu and Yang, 2017) [70]. The KLD database contains a wide range of corporate social responsibility ratings, including seven key stakeholder attributes: community, employee relations, diversity, environment, human rights, product 
quality, and corporate governance. At the same time, there are multiple sub-dimensions within each dimension. For example, environmental issues include waste management, environment, climate change, and water pressure. Social issues include the performance of issues such as community participation, human rights, union relations, labor diversity, and funding access. Governance issues include the implementation of issues such as report quality, corruption, and political instability, financial system instability, governance structure, and business ethics (Khan et al., 2016) [50]. In addition, the KLD database also includes six exclusive screening categories, namely, alcohol, gambling, military contracting, nuclear energy, and tobacco.

In terms of measurement, KLD is a binary system that includes "strengths" and "concerns" (weaknesses). "Strengths" are policies, procedures, and results that can help companies to produce a positive impact on key issues-that is, socially responsible behavior. However, "concerns" are the opposite. In the KLD database, " 1 " is used to indicate the existence of screening (standard), and " 0 " is used to indicate its absence. In other words, if a company meets the description of the evaluation item, the company's score is " 1 ". Otherwise, it is " 0 ". Therefore, the overall evaluation project score reflects the overall level of the company's corporate social responsibility participation. Specifically, two methods are used to measure ESG as a whole or in various dimensions. First, the KLD index can be constructed by accumulating all of the "strengths" items related to research variables. In addition, it can also be measured by constructing a "net" KLD index. The usual practice is constructing the KLD index by calculating the difference between the total "strengths" and the total "concerns" after accumulating the two indexes separately. However, studies have shown that this method has certain shortcomings. Due to the lack of convergence effectiveness of KLD's "strengths" and "concerns," it is difficult to provide an effective corporate social responsibility measurement standard (Kacperczyk, 2009) [76]. Therefore, the empirical analysis of ESG research focuses more on the cumulative method, and the "net" KLD index can be used as a robustness test. In addition, there are studies performing further processing based on the ESG score measurement method. The standardized scores of each category in the selected categories are averaged to calculate the annual composite score of each company. This kind of corporate social responsibility index can not only conduct a simple assessment of corporate social responsibility actions, but is also usually used by professionals to assess the degree of corporate social responsibility effort as a comprehensive index (Chatterji et al., 2016) [73].

\section{Measurement based on Thomson Reuters ASSET4 Database}

Thomson Reuters ASSET4 specializes in providing objective, relevant, and systematic non-financial ESG information and investment analysis tools for professional investors. The database has been providing comprehensive corporate social responsibility data for companies in the Russell 1000 since 2002. Its data sources generally include stock exchange literature, annual financial, and sustainability reports, as well as the websites of nongovernmental organizations and various news sources. Its dedicated research analysts collected 900 evaluation points for each company, and all data used must be objective and public. After collecting the annual ESG data, analysts unified the units for quantitative analysis of these qualitative data. The database mainly focuses on the finance, corporate governance, environmental, and social aspects. In the environmental dimension, the data include energy use, water recycling, carbon dioxide emissions, waste recycling, and spill and pollution disputes. In the social dimension, the data include employee turnover, injury rates, training hours, female employees, donations, and health and security disputes. In the governance dimension, the data include executive compensation, board experience, board diversity, anti-takeover devices, and pay-cheque disputes. The data are divided into two categories: "drivers" and "outcomes." "Drivers" refer to policies on issues such as emission reduction, human rights, and shareholder rights. "Outcomes" refer to quantitative results of greenhouse gas emissions, personnel turnover, and maximum salary packages. 
Table 5. Organization of data sources for ESG score construction.

\begin{tabular}{|c|c|c|c|c|c|}
\hline Databases & Advantages & Disadvantages & Measurement & Scoring & Sources \\
\hline \multirow[b]{2}{*}{$\begin{array}{c}\text { KLD } \\
\text { Database }\end{array}$} & $\begin{array}{l}\text { 1. The data cover a wide } \\
\text { range of industries and a } \\
\text { long period. } \\
\text { 2. Providing relevant } \\
\text { information on }\end{array}$ & \multirow[b]{2}{*}{ / } & Cumulative Addition & $\begin{array}{c}\text { By accumulating all of the } \\
\text { "strengths" items of KLD related } \\
\text { to the research. }\end{array}$ & $\begin{array}{l}\text { Lee, D. Corporate social } \\
\text { responsibility of U.S.-listed } \\
\text { firms headquartered in tax } \\
\text { havens. Strateg. Manag. J. 2020, } \\
\text { 41(9), 1547-1571. [77], etc. }\end{array}$ \\
\hline & $\begin{array}{l}\text { specific issues in a } \\
\text { standardized form. } \\
\text { The database is used by } \\
\text { professional investors and } \\
\text { is a comprehensive data } \\
\text { source to track corporate } \\
\text { social performance. }\end{array}$ & & Net Score & $\begin{array}{l}\text { By accumulating the total } \\
\text { "strengths" and the total } \\
\text { "concerns" and calculating the } \\
\text { difference between the them. }\end{array}$ & $\begin{array}{l}\text { Jia, Y.; Gao, X.; Julian, S. Do } \\
\text { firms use corporate social } \\
\text { responsibility to insure against } \\
\text { stock price risk? Evidence from } \\
\text { a natural experiment. Strateg. } \\
\text { Manag. J. 2020, 41(2), } \\
\text { 290-307. [71], etc. }\end{array}$ \\
\hline $\begin{array}{l}\text { Thomson Reuters } \\
\text { ASSET4 Database }\end{array}$ & $\begin{array}{l}\text { Comprehensive data, focusing on } \\
\text { finance, environment, society, } \\
\text { and governance. }\end{array}$ & $\begin{array}{l}\text { 1. The time series of the } \\
\text { database are short. } \\
\text { 2. Few US companies } \\
\text { are covered. }\end{array}$ & \multicolumn{2}{|c|}{$\begin{array}{l}\text { Measuring ESG as a whole usually uses annual environmental, } \\
\text { social, and governance scores and constructs a corporate social } \\
\text { responsibility index by assigning equal weight to each pillar in } \\
\text { the three dimensions. The corporate social responsibility index } \\
\text { is the average of the three ESG indexes, or the equally weighted } \\
\text { average of the company's environmental, social, and } \\
\text { governance scores. }\end{array}$} & $\begin{array}{l}\text { Kim, S.; Lee, G.; Kang, H.G. } \\
\text { Risk management and } \\
\text { corporate social responsibility. } \\
\text { Strateg. Manag. J. 2021, 42(1), } \\
\text { 202-230. [72], etc. }\end{array}$ \\
\hline
\end{tabular}


In terms of measurement, studies that measure ESG overall usually select annual environmental scores, social scores, and governance scores to construct a corporate social responsibility index by assigning equal weight to each pillar in the three dimensions. The corporate social responsibility index is the average of the three ESG indexes (Kim et al., 2021) [72] or the equally weighted average of the company's environmental, social, and governance scores (Cheng et al., 2014; Surroca et al., 2020) [21,66]. In addition, some studies only select the environmental (E) and social (S) dimensions (Lys et al., 2015) [64] or only the social (S) dimension (Kim et al., 2021) [72].

In summary, this paper systematically examined and summarized the research of ESG through the combination of a bibliometric analysis and a literature review. It was found that the research related to ESG is mainly divided into five modules: the theoretical basis of ESG, the interaction between the three dimensions of ESG, the impact of ESG on economic consequences, the risk prevention role of ESG, and ESG measurement. These studies are mainly based on three dimensions, namely environmental, social, and governance. They not only focus on the interaction between these three dimensions, but also emphasize the role and significance of each individual dimension in ESG.

Therefore, based on the analysis of ESG research progress, this paper further refines the specific characteristics of ESG research and proposes the future research direction of ESG (see Figure 4).

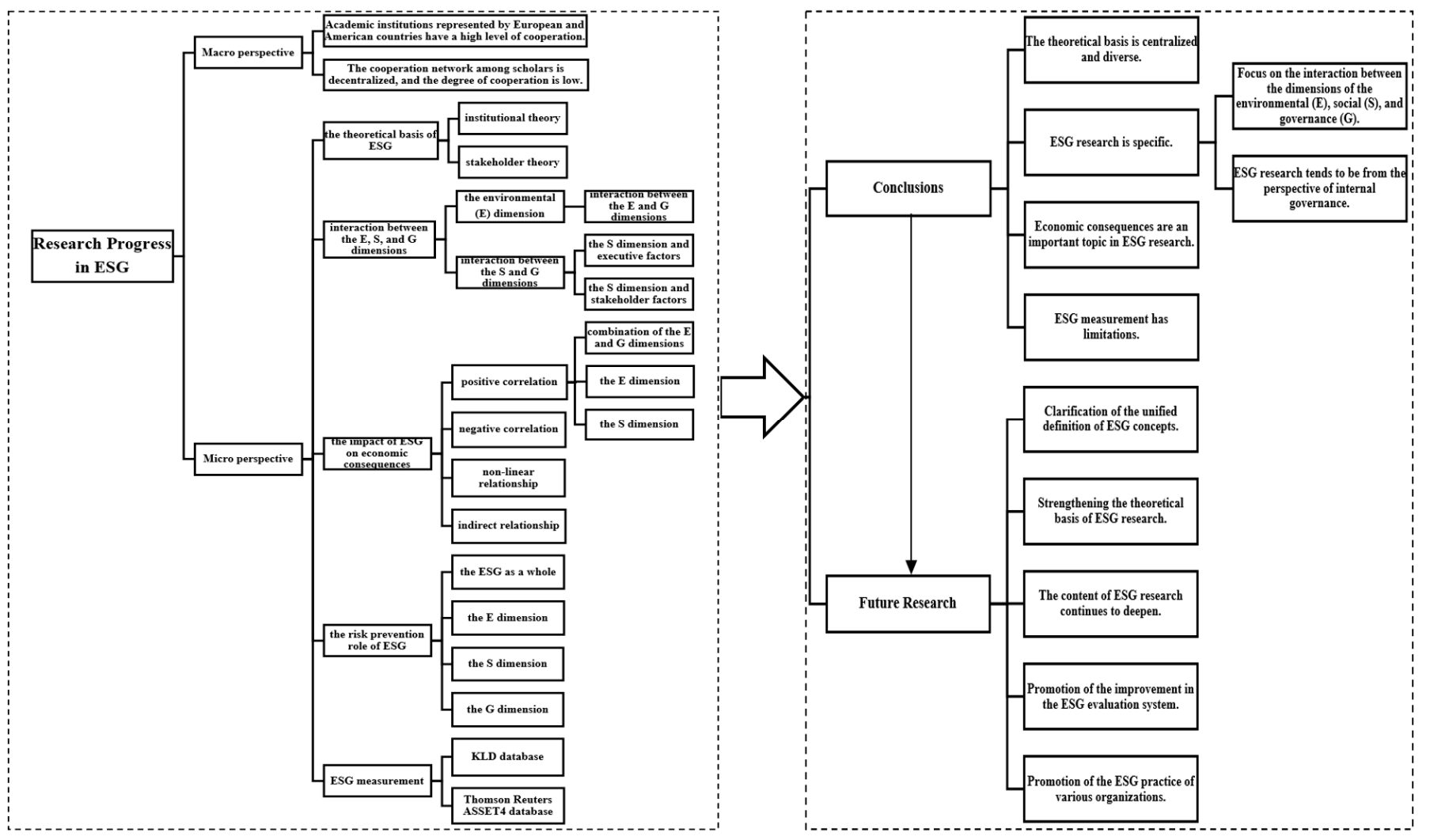

Figure 4. Research progress and future prospects.

\section{Conclusions and Future Research}

\subsection{Conclusions}

This paper systematically examined and analyzed the research progress of ESG, and the conclusions presented below were drawn.

\subsubsection{The Theoretical Basis Is Centralized and Diverse}

The theoretical basis of ESG research is mainly based on "institutional theory" and "stakeholder theory." From the keyword co-occurrence map (see Figure 3), "institutional 
theory" is an important topic of ESG research. In terms of word frequency statistics (see Tables 2 and 3), "institutional theory" became the focus of ESG research in 2011, with a frequency of 23 and a centrality of 0.02 , and "stakeholder theory" became the focus of ESG research in 2007, with a frequency of 19 and a centrality of 0.02 . In addition, from the statistics of the burst terms (see Table 4), "stakeholder theory" became a hot topic from 2012 to 2013, with an intensity of 2.97. The decision making and sustainable development of enterprises are interdependent with their stakeholders. Moreover, the production and development of enterprises depend on their legitimate activities in the internal and external environments. This is the reason for the current research's focus on these two theories.

However, through a literature review, we found that there are also studies on naturalresource-based theory, resource dependence theory, affect-as-information theory, place attachment theory, upper echelons theory, signaling theory, agency theory, attribution theory, transaction cost theory, system justification theory, and social identity theory. Different studies start from different angles and objects to study the performance and effect of ESG in various aspects. Therefore, ESG research appeared to be centralized and possess diverse characteristics in terms of theoretical basis.

\subsubsection{ESG Research Is Specific}

1. Focus on the interaction between the dimensions of the environmental (E), social (S), and governance $(\mathrm{G})$.

From the perspective of word frequency (see Table 2) and centrality (see Table 3), the related keywords include corporate social responsibility, performance, sustainability, management, financial performance, social responsibility, governance, organization, behavior, responsibility, firm performance, shareholder value, green, environment, environmental performance, and firm value. Through the analysis of the research progress, it was found that the research mainly focuses on the interaction between the environmental (E) and governance $(\mathrm{G})$ dimensions and between the social $(\mathrm{S})$ and governance $(\mathrm{G})$ dimensions. Specifically, on the one hand, in terms of the research on the environmental (E) dimension, the previous literature focused on the interaction between the environmental (E) and governance $(\mathrm{G})$ dimensions. The literature showed that the participation of executives and stakeholders is conducive to good environmental performance. At the same time, good performance in aspects such as environmental disclosure is not only conducive to improving environmental performance, but also to building the company's environmental reputation, which is beneficial to the sustainable development of enterprises. On the other hand, the social (S) and governance $(\mathrm{G})$ dimensions are a group of dimensions with the highest frequency in the literature. They mainly focus on the interaction between the social (S) dimension and executive factors and between the social (S) dimension and stakeholder factors. The personality, values, political ideology, age, and other variables of executives affect social responsibility actions and the degree of commitment. Similarly, investment in social responsibility also affects internal governance activities.

2. ESG research tends to be from the perspective of internal governance.

Firstly, from the statistics of the burst terms (see Table 4), the keywords developed from "company" to "incentive" and "director" from 2004 to 2020. The theme of the research shows the trend and characteristics from macro to micro. Secondly, from the statistics of the keywords (see Tables 2 and 3), the keywords related to internal governance include governance, organization, behavior, shareholder value, identity, capability, determinant, stakeholder theory, choice, corporate governance, ownership, consumer, disclosure, work, self-regulation, and commitment. Accounting for nearly one-third of the top 50 keywords, internal governance is the research focus of ESG. It is embodied in the interaction between executive factors and the social (S) dimension, the interaction between executive factors and the environmental (E) dimension, the interaction between stakeholder factors and the social (S) dimension, the interaction between stakeholder factors and the environmental (E) dimension, 
and the role of governance $(\mathrm{G})$ in risk prevention. Therefore, in terms of the research hot topic and contents, ESG research is more inclined to the perspective of internal governance.

\subsubsection{Economic Consequences Are an Important Topic in ESG Research}

The keyword co-occurrence map demonstrated that "organizational performance" is one of the issues of ESG research (see Figure 3). In terms of the importance of research, the research on the impact of ESG on economic consequences has always been a hot topic. Firstly, "financial performance" was a hot research topic in 2006 and 2016, with word frequency of 83 and 16 and centrality of 0.06 and 0.02 , respectively (see Tables 2 and 3). Moreover, "firm performance" became a hot research topic in 2010, with a word frequency of 30 and a centrality of 0.02. In addition, "firm value" became a hot research topic in 2017, with a word frequency of 14 and a centrality of 0.01 . Therefore, it can be seen from the distribution of time that economic consequences have always been a hot topic in ESG research. Secondly, from the statistics of the burst terms (see Table 4), "financial performance" was a hot research topic in 2016-2017, with an intensity of 4.75, ranking first. Moreover, "firm value" was a hot topic from 2017 to 2020, with an intensity of 3.67. These topics all show high outbreak intensity, which can sufficiently explain the important position of economic consequences in ESG research. Moreover, in terms of research content, it is mainly divided into four parts: positive correlation, negative correlation, non-linear relationship, indirect relationship. Regarding the dimensions, it mainly focuses on the combination of the environmental (E) and social (S) dimensions, a separate environmental (E) dimension, and a separate social (S) dimension to measure the impact of ESG on the economic consequences of enterprises.

However, from the statistical results of the word frequency and centrality of keywords and the analysis results of the burst terms, "firm value" is a topic that has only emerged in recent years in ESG research. Firm value can reflect a company's future value-adding capabilities, risk control, and other capabilities of sustainable development, which are vital to its future growth. Similarly, ESG, as a value that considers the sustainable and coordinated development of economic, environmental, social, and governance benefits, and an investment philosophy that pursues long-term value growth, coincides with the importance of firm value. Hence, future research focusing on exploring the relationship between ESG and firm value is of vital importance to further verify companies' sustainable development capabilities.

\subsubsection{ESG Measurement Has Limitations}

Through a systematic literature review, we found that the commonly used ESG data have the following two characteristics: on the one hand, because ESG research is an emerging topic, the data mainly come from the KLD database and Thomson Reuters ASSET4 database. However, there are certain differences in the measured dimensions and criteria for selection. Therefore, the lack of a unified standard for measurement may lead to deviations in the results of various studies. On the other hand, although existing research institutions have formed ESG measurement and evaluation systems, they are relatively limited in terms of the diversity and breadth. In the current research, although the KLD database and Thomson Reuters ASSET 4 database maintain their mainstream status, ESG, as a comprehensive measure to solve the global sustainable development problem, should be embedded in different institutional backgrounds and industry characteristics. The validity and reliability of the KLD database and Thomson Reuters ASSET4 database in ESG measurement in emerging countries remain to be considered. Therefore, we should not only unify the standards globally to improve their credibility and persuasiveness, but also consider the special institutional background of each country and the characteristics of different industries; therefore, we should analyze some specific problems and establish a comprehensive and mature ESG measurement system. We look forward to the further improvement of the ESG measurement system to facilitate academic research on ESG. 


\subsection{Future Research}

Based on the above review of the contents and limitations of ESG research, we look forward to furthering the advancement of ESG research in the following aspects.

1. Clarification of the unified definition of ESG concepts.

ESG, as a non-financial index of enterprises, represents the practice and performance of an enterprise in terms of environmental, social, and governance. Before the concept of ESG was widely known, it was usually called "responsible investment" and was also defined as "CSR." Therefore, the concept of ESG has not yet been unified and clarified. In addition, there are differences in the selection of ESG index types in various dimensions, which results in the inconsistency of the definition of ESG and its dimensions. This, in turn, affects the authority and credibility of the definition of ESG. In the future, academic institutions and scholars in various countries should strengthen cooperation and continue to endeavor to define the ESG concept and the deepening of ESG research.

2. Strengthening the theoretical basis of ESG research.

The theoretical basis of ESG research is centralized and diverse, mainly based on "institutional theory" and "stakeholder theory." Meanwhile, there is also research based on natural-resource-based theory, resource dependence theory, affect-as-information theory, place attachment theory, upper echelons theory, signaling theory, agency theory, attribution theory, transaction cost theory, system justification theory, and social identity theory. However, to date, there has not been a unified and appropriate theoretical basis that can systematically explain the internal mechanism of corporate ESG practice. Therefore, with the development and maturity of ESG research, further exploration and improvement are needed in the theoretical basis in the future.

3. The content of ESG research continues to deepen.

Through the analysis of the second part, we found that ESG research gradually showed a more detailed feature. In terms of content, it focuses on the interaction between various dimensions and on internal governance. However, there is still room for further improvement. On the one hand, there is a lack of research on the interaction between the environmental (E) and social (S) dimensions. The reason for this is that the existing studies usually classify the environmental (E) dimension as a social (S) dimension. They rarely study it as a separate dimension, which is specifically reflected in the selection of ESG indexes. From the perspective of sustainable development, the environmental (E) issue is one of the important issues, since it is the basis for the sustainable development of the economy and society. In the future, the environmental (E) dimension should be separated from the social $(S)$ dimension. Furthermore, future studies should aim to explore the relationship between the environmental (E) and social (S) dimensions, enrich the interactive research between the environmental (E) and governance $(\mathrm{G})$ dimensions, and highlight the significance and importance of the environmental (E) dimension under the theme of ESG. On the other hand, the governance $(\mathrm{G})$ dimension is the focus of ESG research, but there are few studies on the relationship between governance $(G)$ and economic consequences. Although the influencing factors of economic consequences are a multidimensional comprehensive embodiment, governance (G), as the core of management, is an important factor affecting firm performance. With the development of the economy and society, governance $(G)$ is an important factor in further promoting high-quality development. In the future, we should further explore the research of governance $(G)$ regarding the impact of ESG on economic consequences.

Therefore, ESG, as an important factor affecting the investment and return of enterprises, continues to deepen the research content of ESG, forms a complete closed loop, and explores the importance of ESG in the process of sustainable development from a more specific and detailed perspective, which is of great significance for future research.

4. Promotion of the improvement in the ESG evaluation system. 
An effective and consistent evaluation system is a standard for measuring the sustainable development activities of various enterprises in the industry. In the literature, the evaluation system used for ESG measurement is mainly based on the relevant data in the KLD database and Thomson Reuters ASSET4 database. However, the overall ESG and the standards of various dimensions measured by various databases lack uniformity. Most of the evaluation systems are established using expert scoring, and so there is a certain degree of subjectivity. At the same time, the database lacks applicability and feasibility based on different national systems and industry backgrounds. Therefore, a unified and mature ESG evaluation system is the foundation for the study of corporate sustainable development, the key to the credibility of corporate social responsibility information disclosure, and a quantitative standard for promoting the effectiveness of ESG practices. Simple, accurate, and efficient quantitative methods guarantee the implementation of ESG concepts and are also important modules that need to be further clarified in future research.

5. Promotion of the ESG practice of various organizations.

ESG is the core framework for enterprises to pursue sustainable development. Integrating it into business management and investment decision making has become an international passport for enterprises to practice sustainable development. Through the analysis and summary of ESG research progress, we expect to provide substantive enlightenment and suggestions to enterprises, government regulators, financial institutions, and academic institutions. Firstly, in terms of enterprises, companies should re-examine internal governance to consider how to give full play to the positive impact of ESG on the economic consequences with regard to the aspects of senior management appointment and organizational structure design and employee training in order to actively build effective risk prevention and a "protection" mechanism. Secondly, in terms of government regulators, based on fully understanding the importance of ESG practice in sustainable development, reasonable policies, regulations, and information disclosure systems should be formulated to standardize enterprise behavior. At the same time, the construction and unification of the ESG evaluation system should be actively promoted to provide a basis for the investment decision making of financial institutions. In addition, in terms of financial institutions, through the systematic analysis of governance $(G)$, we could provide more detailed and comprehensive non-data investment decision-making information for financial institutions. Moreover, we assume that financial institutions will be able to provide substantive suggestions for improving the ESG evaluation system from the perspective of practice. Finally, in terms of academic institutions, through the review of ESG research, we clarified the context of ESG research, summarized the characteristics of the past research in terms of trends and content, and highlighted the shortcomings in order to propose several future research directions and a vision for the future research of ESG.

Author Contributions: Writing: T.-T.L.; providing ideas and data: T.-T.L. and K.W.; providing revised advice: T.S. and D.D.W. All authors have read and agreed to the published version of the manuscript.

Funding: This research was funded by Beijing Social Science Fund Project (grant number: 18GLC076).

Institutional Review Board Statement: Not applicable.

Informed Consent Statement: Not applicable.

Data Availability Statement: Not applicable.

Conflicts of Interest: The authors declare no conflict of interest.

\section{References}

1. EBA. EBA Report on Management and Supervision of ESG Risks for Credit Institutions and Investment Firms. Available online: https:/ / www.eba.europa.eu/sites/default/documents/fifiles/document_library/Publications/Reports/2021/10156 56/EBA\%20Report\%20on\%20ESG\%20risks\%20management\%20and\%20supervision.pdf (accessed on 31 July 2021).

2. PRI. What is Responsible Investment? Available online: https://www.unpri.org/an-introduction-to-responsible-investment/ what-is-responsible-investment/4780.article (accessed on 31 July 2021). 
3. EBA. Environmental Social and Governance Disclosures. Available online: https://www.eba.europa.eu/sites/default/ documents/files/document_library / Publications /Consultations/2021/Consultation\%20on\%20draft \%20ITS\%20on\%20Pillar\% 20disclosures\%20on\%20ESG\%20risk/963626/Factsheet\%20-\%20ESG\%20disclosures.pdf (accessed on 31 July 2021).

4. Daugaard, D. Emerging new themes in environmental, social and governance investing: A systematic literature review. Account. Financ. 2020, 60, 1501-1530. [CrossRef]

5. Widyawati, L. A systematic literature review of socially responsible investment and environmental social governance metrics. Bus. Strateg. Environ. 2020, 29, 619-637. [CrossRef]

6. Drempetic, S.; Klein, C.; Zwergel, B. The influence of firm size on the ESG score: Corporate sustainability ratings under review. J. Bus. Ethics 2020, 167, 333-360. [CrossRef]

7. Eccles, N.S.; Viviers, S. The origins and meanings of names describing investment practices that integrate a consideration of ESG issues in the academic literature. J. Bus. Ethics 2011, 104, 389-402. [CrossRef]

8. Ziolo, M.; Filipiak, B.Z.; Bak, I.; Cheba, K. How to design more sustainable financial systems: The roles of environmental, social, and governance factors in the decision-making process. Sustainability 2019, 11, 5604. [CrossRef]

9. Yoshikawa, T.; Nippa, M.; Chua, G. Global shift towards stakeholder-oriented corporate governance? Evidence from the scholarly literature and future research opportunities. Multinatl. Bus. Rev. 2021, 29, 321-347. [CrossRef]

10. Aluchna, M.; Roszkowska-Menkes, M. Integrating corporate social responsibility and corporate governance at the company level. Towards a conceptual model. Eng. Econ. 2019, 30, 349-361. [CrossRef]

11. Garcia, A.S.; Mendes-Da-Silva, W.; Orsato, R.J. Sensitive industries produce better ESG performance: Evidence from emerging markets. J. Clean. Prod. 2017, 150, 135-147. [CrossRef]

12. Chatterji, A.K.; Toffel, M.W. How firms respond to being rated. Strateg. Manag. J. 2010, 31, 917-945. [CrossRef]

13. Jayachandran, S.; Kalaignanam, K.; Eilert, M. Product and environmental social performance: Varying effect on firm performance. Strateg. Manag. J. 2013, 34, 1255-1264. [CrossRef]

14. Koh, P.-S.; Qian, C.; Wang, H. Firm litigation risk and the insurance value of corporate social performance. Strateg. Manag. J. 2014, 35, 1464-1482. [CrossRef]

15. Flammer, C.; Hong, B.; Minor, D. Corporate governance and the rise of integrating corporate social responsibility criteria in executive compensation: Effectiveness and implications for firm outcomes. Strateg. Manag. J. 2019, 40, 1097-1122. [CrossRef]

16. Kölbel, J.F.; Busch, T.; Jancso, L.M. How media coverage of corporate social irresponsibility increases financial risk. Strateg. Manag. J. 2017, 38, 2266-2284. [CrossRef]

17. Surroca, J.; Tribó, J.A.; Waddock, S. Corporate responsibility and financial performance: The role of intangible resources. Strateg. Manag. J. 2010, 31, 463-490. [CrossRef]

18. Muller, A.; Kräussl, R. Doing good deeds in times of need: A strategic perspective on corporate disaster donations. Strateg. Manag. J. 2011, 32, 911-929. [CrossRef]

19. Flammer, C.; Kacperczyk, A. Corporate social responsibility as a defense against knowledge spillovers: Evidence from the inevitable disclosure doctrine. Strateg. Manag. J. 2019, 40, 1243-1267. [CrossRef]

20. Davidson, R.H.; Dey, A.; Smith, A.J. CEO materialism and corporate social responsibility. Account. Rev. 2019, 94, 101-126. [CrossRef]

21. Cheng, B.; Ioannou, I.; Serafeim, G. Corporate social responsibility and access to finance. Strateg. Manag. J. 2014, 35, 1-23. [CrossRef]

22. Kim, Y.; Park, M.S.; Wier, B. Is earnings quality associated with corporate social responsibility? Account. Rev. 2012, 87, 761-796. [CrossRef]

23. Gao, F.; Lisic, L.L.; Zhang, I.X. Commitment to social good and insider trading. J. Account. Econ. 2014, 57, 149-175. [CrossRef]

24. Hubbard, T.D.; Christensen, D.M.; Graffin, S.D. Higher highs and lower lows: The role of corporate social responsibility in CEO dismissal. Strateg. Manag. J. 2017, 38, 2255-2265. [CrossRef]

25. Fu, R.; Tang, Y.; Chen, G. Chief sustainability officers and corporate social (Ir)responsibility. Strateg. Manag. J. 2020, 41, 656-680. [CrossRef]

26. Tang, Y.; Qian, C.; Chen, G.; Shen, R. How CEO hubris affects corporate social (ir)responsibility. Strateg. Manag. J. 2015, 36, 1338-1357. [CrossRef]

27. Petrenko, O.V.; Aime, F.; Ridge, J.; Hill, A. Corporate social responsibility or CEO narcissism? CSR motivations and organizational performance. Strateg. Manag. J. 2016, 37, 262-279. [CrossRef]

28. Tang, Y.; Mack, D.Z.; Chen, G. The differential effects of CEO narcissism and hubris on corporate social responsibility. Strateg. Manag. J. 2018, 39, 1370-1387. [CrossRef]

29. Hafenbrädl, S.; Waeger, D. Ideology and the micro-foundations of CSR: Why executives believe in the business case for CSR and how this affects their CSR engagements. Acad. Manag. J. 2017, 60, 1582-1606. [CrossRef]

30. Chin, M.K.; Hambrick, D.C.; Treviño, L.K. Political ideologies of CEOs: The influence of executives' values on corporate social responsibility. Adm. Sci. Q. 2013, 58, 197-232. [CrossRef]

31. Gupta, A.; Nadkarni, S.; Mariam, M. Dispositional sources of managerial discretion: CEO ideology, CEO personality, and firm strategies. Adm. Sci. Q. 2019, 64, 855-893. [CrossRef]

32. Gupta, A.; Fung, A.; Murphy, C. Out of character: CEO political ideology, peer influence, and adoption of CSR executive position by Fortune 500 firms. Strateg. Manag. J. 2021, 42, 529-557. [CrossRef] 
33. Kang, J. Labor market evaluation versus legacy conservation: What factors determine retiring CEOs' decisions about long-term investment? Strateg. Manag. J. 2016, 37, 389-405. [CrossRef]

34. Lai, S.; Li, Z.; Yang, Y.G. East, west, home's best: Do local CEOs behave less myopically? Account. Rev. 2020, 95, 227-255. [CrossRef]

35. Bertrand, O.; Betschinger, M.-A.; Moschieri, C. Are firms with foreign CEOs better citizens? A study of the impact of CEO foreignness on corporate social performance. J. Int. Bus. Stud. 2021, 52, 525-543. [CrossRef]

36. Church, B.K.; Jiang, W.; Kuang, X.; Vitalis, A. A dollar for a tree or a tree for a dollar? The behavioral effects of measurement basis on managers' CSR investment decision. Account. Rev. 2019, 94, 117-137. [CrossRef]

37. Han, Q.; Jennings, J.E.; Liu, R.; Jennings, P.D. Going home and helping out? Returnees as propagators of CSR in an emerging economy. J. Int. Bus. Stud. 2019, 50, 857-872. [CrossRef]

38. Luo, J.; Chen, J.; Chen, D. Coming back and giving back: Transposition, institutional actors, and the paradox of peripheral influence. Adm. Sci. Q. 2021, 66, 133-176. [CrossRef]

39. Li, S.; Lu, J.W. A dual-agency model of firm CSR in response to institutional pressure: Evidence from Chinese publicly listed firms. Acad. Manag. J. 2020, 63, 2004-2032. [CrossRef]

40. Madsen, P.M.; Rodgers, Z.J. Looking good by doing good: The antecedents and consequences of stakeholder attention to corporate disaster relief. Strateg. Manag. J. 2015, 36, 776-794. [CrossRef]

41. Flammer, C.; Luo, J. Corporate social responsibility as an employee governance tool: Evidence from a quasi-experiment. Strateg. Manag. J. 2017, 38, 163-183. [CrossRef]

42. Balakrishnan, R.; Sprinkle, G.B.; Williamson, M.G. Contracting benefits of corporate giving: An experimental investigation. Account. Rev. 2011, 86, 1887-1907. [CrossRef]

43. Carnahan, S.; Kryscynski, D.; Olson, D. When does corporate social responsibility reduce employee turnover? Evidence from attorneys before and after 9/11. Acad. Manag. J. 2017, 60, 1932-1962. [CrossRef]

44. Farooq, O.; Rupp, D.E.; Farooq, M. The multiple pathways through which internal and external corporate social responsibility influence organizational identification and multifoci outcomes: The moderating role of cultural and social orientations. Acad. Manag. J. 2017, 60, 954-985. [CrossRef]

45. Elliott, W.B.; Jackson, K.E.; Peecher, M.E.; White, B.J. The unintended effect of corporate social responsibility performance on investors' estimates of fundamental value. Account. Rev. 2014, 89, 275-302. [CrossRef]

46. Muller, A.R.; Pfarrer, M.D.; Little, L.M. A theory of collective empathy in corporate philanthropy decisions. Acad. Manag. Rev. 2014, 39, 1-21. [CrossRef]

47. Gupta, A.; Briscoe, F.; Hambrick, D.C. Red, blue, and purple firms: Organizational political ideology and corporate social responsibility. Strateg. Manag. J. 2017, 38, 1018-1040. [CrossRef]

48. Mun, E.; Jung, J. Change above the glass ceiling: Corporate social responsibility and gender diversity in Japanese firms. Adm. Sci. Q. 2018, 63, 409-440. [CrossRef]

49. Naughton, J.P.; Wang, C.; Yeung, I. Investor sentiment for corporate social performance. Account. Rev. 2019, 94, 401-420. [CrossRef]

50. Khan, M.; Serafeim, G.; Yoon, A. Corporate sustainability: First evidence on materiality. Account. Rev. 2016, 91, 1697-1724. [CrossRef]

51. Awaysheh, A.; Heron, R.A.; Perry, T.; Wilson, J.I. On the relation between corporate social responsibility and financial performance. Strateg. Manag. J. 2020, 41, 965-987. [CrossRef]

52. Mackey, A.; Mackey, T.B.; Barney, J.B. Corporate social responsibility and firm performance: Investor preferences and corporate strategies. Acad. Manag. Rev. 2007, 32, 817-835. [CrossRef]

53. Barnett, M.L.; Salomon, R.M. Beyond dichotomy: The curvilinear relationship between social responsibility and financial performance. Strateg. Manag. J. 2006, 27, 1101-1122. [CrossRef]

54. Matsumura, E.M.; Prakash, R.; Vera-Muñoz, S.C. Firm-value effects of carbon emissions and carbon disclosures. Account. Rev. 2014, 89, 695-724. [CrossRef]

55. Godfrey, P.C. The relationship between corporate philanthropy and shareholder wealth: A risk management perspective. Acad. Manag. Rev. 2005, 30, 777-798. [CrossRef]

56. Wang, H.; Qian, C. Corporate philanthropy and corporate financial performance: The roles of stakeholder response and political access. Acad. Manag. J. 2011, 54, 1159-1181. [CrossRef]

57. Kaul, A.; Luo, J. An economic case for CSR: The comparative efficiency of for-Profit firms in meeting consumer demand for social goods. Strateg. Manag. J. 2018, 39, 1650-1677. [CrossRef]

58. Manchiraju, H.; Rajgopal, S. Does corporate social responsibility (CSR) create shareholder value? Evidence from the Indian companies Act 2013. J. Account. Res. 2017, 55, 1257-1300. [CrossRef]

59. Chen, Y.-C.; Hung, M.; Wang, Y. The effect of mandatory CSR disclosure on firm profitability and social externalities: Evidence from China. J. Account. Econ. 2018, 65, 169-190. [CrossRef]

60. Barnett, M.L.; Salomon, R.M. Does it pay to be really good? Addressing the shape of the relationship between social and financial performance. Strateg. Manag. J. 2012, 33, 1304-1320. [CrossRef]

61. Zhao, X.; Murrell, A.J. Revisiting the corporate social performance-financial performance link: A replication of Waddock and Graves. Strateg. Manag. J. 2016, 37, 2378-2388. [CrossRef] 
62. Hull, C.E.; Rothenberg, S. Firm performance: The interactions of corporate social performance with innovation and industry differentiation. Strateg. Manag. J. 2008, 29, 781-789. [CrossRef]

63. Ramchander, S.; Schwebach, R.G.; Staking, K. The informational relevance of corporate social responsibility: Evidence from DS400 index reconstitutions. Strateg. Manag. J. 2012, 33, 303-314. [CrossRef]

64. Lys, T.; Naughton, J.P.; Wang, C. Signaling through corporate accountability reporting. J. Account. Econ. 2015, 60, 56-72. [CrossRef]

65. Hawn, O.; Ioannou, I. Mind the gap: The interplay between external and internal actions in the case of corporate social responsibility. Strateg. Manag. J. 2016, 37, 2569-2588. [CrossRef]

66. Surroca, J.A.; Aguilera, R.V.; Desender, K.; Tribó, J.A. Is managerial entrenchment always bad and corporate social responsibility always good? A cross-national examination of their combined influence on shareholder value. Strateg. Manag. J. 2020, 41, 891-920. [CrossRef]

67. Mithani, M.A. Liability of foreignness, natural disasters, and corporate philanthropy. J. Int. Bus. Stud. 2017, 48, 941-963. [CrossRef]

68. Zhou, N.; Wang, H. Foreign subsidiary CSR as a buffer against parent firm reputation risk. J. Int. Bus. Stud. 2020, 51, 1256-1282. [CrossRef]

69. Flammer, C. Corporate social responsibility and shareholder reaction: The environmental awareness of investors. Acad. Manag. J. 2013, 56, 758-781. [CrossRef]

70. Shiu, Y.-M.; Yang, S.-L. Does engagement in corporate social responsibility provide strategic insurance-like effects? Strateg. Manag. J. 2017, 38, 455-470. [CrossRef]

71. Jia, Y.; Gao, X.; Julian, S. Do firms use corporate social responsibility to insure against stock price risk? Evidence from a natural experiment. Strateg. Manag. J. 2020, 41, 290-307. [CrossRef]

72. Kim, S.; Lee, G.; Kang, H.G. Risk management and corporate social responsibility. Strateg. Manag. J. 2021, 42, 202-230. [CrossRef]

73. Chatterji, A.K.; Durand, R.; Levine, D.I.; Touboul, S. Do ratings of firms converge? Implications for managers, investors and strategy researchers. Strateg. Manag. J. 2016, 37, 1597-1614. [CrossRef]

74. Deckop, J.R.; Merriman, K.K.; Gupta, S. The effects of CEO pay structure on corporate social performance. J. Manag. 2006, 32, 329-342. [CrossRef]

75. Ioannou, I.; Serafeim, G. The impact of corporate social responsibility on investment recommendations: Analysts' perceptions and shifting institutional logics. Strateg. Manag. J. 2015, 36, 1053-1081. [CrossRef]

76. Kacperczyk, A. With greater power comes greater responsibility? Takeover protection and corporate attention to stakeholders. Strateg. Manag. J. 2009, 30, 261-285. [CrossRef]

77. Lee, D. Corporate social responsibility of U.S.-listed firms headquartered in tax havens. Strateg. Manag. J. 2020, 41, 1547-1571. [CrossRef] 